Article

\title{
Identification of Subnanometric Ag Species, Their Interaction with Supports and Role in Catalytic CO Oxidation
}

Yulia Kotolevich ${ }^{1}$, Ekaterina Kolobova ${ }^{2}$, Evgeniy Khramov ${ }^{3}$, Jesús Efren Cabrera Ortega ${ }^{4}$, Mario H. Farías ${ }^{1}$, Yan Zubavichus ${ }^{3}$, Rodolfo Zanella ${ }^{5}$, Josué D. Mota-Morales ${ }^{1,6}$, Alexey Pestryakov ${ }^{2}$, Nina Bogdanchikova ${ }^{1}$ and Vicente Cortés Corberán ${ }^{7, *}$

1 Departamento de Fisicoquímica de Nanomateriales, Centro de Nanociencias y Nanotecnología, Universidad Nacional Autónoma de México (UNAM), Ensenada 22860, Mexico;

Julia.Kotolevich@gmail.com (Y.K.); mario@cnyn.unam.mx (M.H.F.);

jmota@cnyn.unam.mx (J.D.M.-M.); nina@cnyn.unam.mx (N.B.)

2 Department of Physical and Analytical Chemistry, Tomsk Polytechnic University, Tomsk 634050, Russia; ekaterina_kolobova@mail.ru (E.K.); pestryakov2005@yandex.ru (A.P.)

3 National Research Center “Kurchatov Institute”, Moscow 123182, Russia; evxramov@gmail.com (E.K.); yzubav@googlemail.com (Y.Z.)

4 Departamento de Fisica Aplicada, Centro de Investigación Científica y de Educación Superior de Ensenada, Ensenada 22860, Mexico; efren507.507@gmail.com

5 Centro de Ciencias Aplicadas y Desarrollo Tecnológico, Universidad Nacional Autónoma de México (UNAM), México, DF 04510, Mexico; rodolfo.zanella@ccadet.unam.mx

6 CONACYT Research Fellow at Centro de Nanociencias y Nanotecnología, UNAM, Ensenada 22860, Mexico

7 Institute of Catalysis and Petroleumchemistry (ICP), Spanish Council for Scientific Research (CSIC), Madrid 28049, Spain

* Correspondence: vcortes@icp.csic.es; Tel.: +34-915-854-783

Academic Editor: Sonia A.C. Carabineiro

Received: 6 February 2016; Accepted: 15 April 2016; Published: 22 April 2016

\begin{abstract}
The nature and size of the real active species of nanoparticulated metal supported catalysts is still an unresolved question. The technique of choice to measure particle sizes at the nanoscale, HRTEM, has a practical limit of $1 \mathrm{~nm}$. This work is aimed to identify the catalytic role of subnanometer species and methods to detect and characterize them. In this frame, we investigated the sensitivity to redox pretreatments of $\mathrm{Ag} / \mathrm{Fe} / \mathrm{TiO}_{2}, \mathrm{Ag} / \mathrm{Mg} / \mathrm{TiO}_{2}$ and $\mathrm{Ag} / \mathrm{Ce} / \mathrm{TiO}_{2}$ catalysts in $\mathrm{CO}$ oxidation. The joint application of HRTEM, SR-XRD, DRS, XPS, EXAFS and XANES methods indicated that most of the silver in all samples is in the form of Ag species with size $<1 \mathrm{~nm}$. The differences in catalytic properties and sensitivity to pretreatments, observed for the studied Ag catalysts, could not be explained taking into account only the Ag particles whose size distribution is measured by HRTEM, but may be explained by the presence of the subnanometer Ag species, undetectable by HRTEM, and their interaction with supports. This result highlights their role as active species and the need to take them into account to understand integrally the catalysis by supported nanometals.
\end{abstract}

Keywords: silver catalysts; subnanometer species; $\mathrm{CO}$ oxidation; sensitivity to pretreatments; interaction with support

\section{Introduction}

The discovery of the extraordinary catalytic activity of gold nanoparticles for oxidation reactions compared to that of the bulk metal sparked the interest on the influence of the metal particle size at the nanometer scale on the catalytic performance of noble metal-based catalysts. In the literature, there are publications describing catalysts active at low temperature that contain both particles undetectable 
by TEM and, in the other extreme, very large particles [1-8]. Difficulties in the interpretation of such results are associated with the limited information provided by the routine physical and chemical research methods of characterization (e.g., XRD and TEM).

Over the last 20 years, only a few papers have explained the atypical behavior of catalysts by the presence of ultra-small particles of gold, i.e., subnanometer clusters [9-13] and atomically dispersed single-site cations $[14,15]$. Modern microscopes, such as aberration-corrected high angle annular dark field scanning transmission microscope (ac-HAADF/STEM), enable one to capture ultra-small particles and atoms $[14,16]$. Another approach for subnanometer clusters' detection is by combining the use of multiple research methods, both more common ones (TPR, UV-VIS) and advanced ones (EXAFS, XANES, XPS, DFT).

Flytzani-Stephanopoulos et al. leached out Au NPs and showed that gold nanoparticles on various supports are not active in the water-gas shift (WGS) reaction [14,17-20]; they are only "spectators" or, in other words, inactive "fillers". Only atomically-dispersed gold cations are the active species, even if they contribute only $3 \%-10 \%$ to the total gold content [19]. These cations were characterized (XPS, EXAFS, XANES, TPR, ac-HAADF/STEM, DFT, etc.), and their catalytic activity was tested after removing weakly-bound clusters and nanoparticles (spectators) by cyanide leaching.

In previous works of our group, the activity of gold catalysts containing particles in the range of 20-700 nm in CO hydrogenation below $400{ }^{\circ} \mathrm{C}$ could be attributed to the presence of subnanometer clusters $[12,13]$. The existence of these clusters was revealed by combining methods, such as UV-VIS, HRTEM and calculations of XRD data with Rietveld refinement [21-23]. Conversely, gold nanoparticles were found to be active for the water-gas shift reaction in other works. Their activity depended on the particle size and the type of interactions established with the support [24-27]. Furthermore, the catalytic activity strongly depended on the method of preparation that, in turn, affected the support used for dispersing the metal.

In contrast to gold, works dedicated to silver subnanometer species are very few. Currently, studies by different groups explain the activity of the silver catalysts supported on $\mathrm{SiO}_{2}$ and $\mathrm{Al}_{2} \mathrm{O}_{3}$ by the presence of subnanometer silver clusters, which were detected by the FTIR of adsorbed CO (FTIR CO) [28-32] and UV-VIS [32-34].

The present work aims to further the field of catalytic properties of subnanometer species and methods to detect them. Our specific goal was to investigate the catalytic properties of silver deposited on active supports composed by $\mathrm{TiO}_{2}$, modified with oxides of $\mathrm{Mg}$, $\mathrm{Fe}$ and $\mathrm{Ce}$, for $\mathrm{CO}$ oxidation. This is an important reaction from both a fundamental viewpoint and practical application to, among others, environmental protection, safety in industrial and residential premises and inside vehicles. The differences found among the catalysts in sensitivity to redox pretreatments could not be explained considering the Ag particle size distributions measured by HRTEM in the interval 1-12 nm, but were explained by the existence of $\mathrm{Ag}$ species with size $<1 \mathrm{~nm}$ non-visible in HRTEM and their interaction with supports.

\section{Results and Discussion}

Figure 1 shows the results of catalytic tests for as-prepared silver catalysts, the second run and after redox pretreatments. According to the literature, oxides, in particular ceria and titania, are not simple spectators, as they can affect the catalytic activity by participating directly in the reaction $[31,32]$ or by modifying the chemical properties of the supported metal [35,36]. However, it can be seen in our case that bare $\mathrm{Ce} / \mathrm{TiO}_{2}$ and $\mathrm{Mg} / \mathrm{TiO}_{2}$ supports do not show significant conversion under the conditions studied. For $\mathrm{Ag} / \mathrm{Ce} / \mathrm{TiO}_{2}$, the light-off curves of catalytic reaction matched the typical S-shaped curve. For $\mathrm{Ag} / \mathrm{Mg} / \mathrm{TiO}_{2}$, there is a combination of a curve with a maximum (at low temperatures) and an S-shaped curve (at high temperatures). This effect, caused by both supported silver $[2,16]$ and gold [37-41] catalysts, is explained in the literature as due to the activity of small clusters and larger particles, at low temperatures and at high temperatures, respectively. It can be seen that light-off curves for as-prepared $\mathrm{Ag} / \mathrm{Ce} / \mathrm{TiO}_{2}$ and $\mathrm{Ag} / \mathrm{Fe} / \mathrm{TiO}_{2}$ samples are similar; consequently, the contents of 
active species in them were comparable (Figure 1). Pretreatments revealed differences in their catalytic behaviors. Light-off curves for $\mathrm{Ag} / \mathrm{Mg} / \mathrm{TiO}_{2}$ samples as-prepared and after different pretreatments vary considerably, while those for $\mathrm{Ag} / \mathrm{Ce} / \mathrm{TiO}_{2}$ turn out to be almost identical. The changes among all light-off curves for $\mathrm{Ag} / \mathrm{Fe} / \mathrm{TiO}_{2}$ represented an intermediate case.

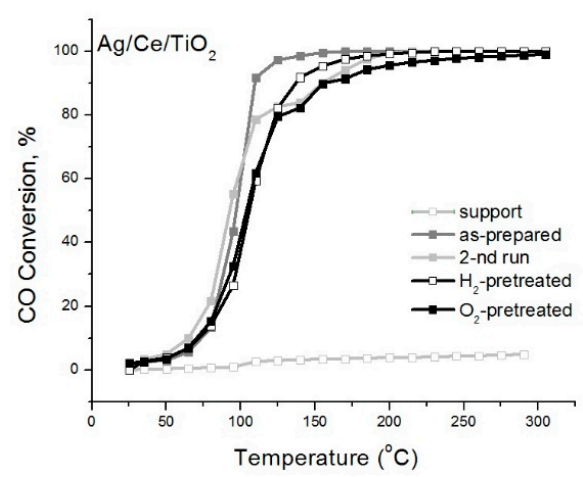

(a)

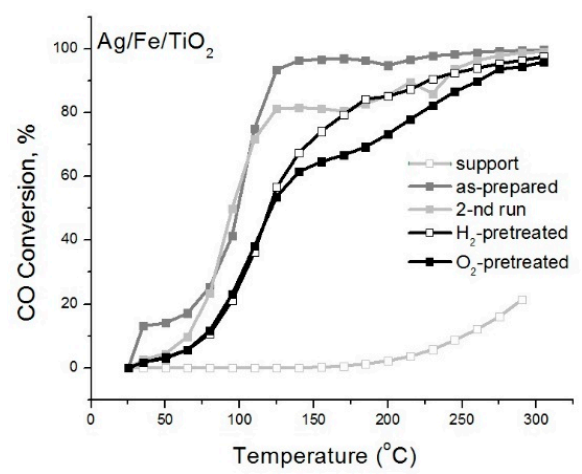

(b)

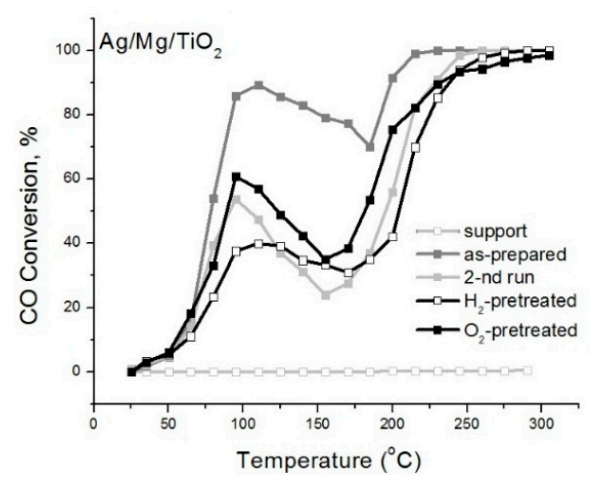

(c)

Figure 1. $\mathrm{CO}$ conversion vs. temperature on $\mathrm{Ag}$ catalysts on $\mathrm{TiO}_{2}$ support modified with $\mathrm{Ce}(\mathbf{a})$; $\mathrm{Fe}(\mathbf{b})$ or $\mathrm{Mg}(\mathbf{c})$.

Different complementary physical and chemical characterization methods were used to investigate the causes of the differences in catalytic behavior. Table 1 shows that the specific surface area of modified supports and catalysts are similar, and the content of Ag is identical for all catalysts, which ruled out these characteristics ( $\mathrm{S}_{\mathrm{BET}}$ and $\mathrm{Ag}$ content) as the source of their distinct catalytic performance.

The particle size distribution for silver catalysts, calculated from HRTEM images, is displayed in Figure 2. An extremely narrow particle size distribution centered at $1 \mathrm{~nm}$ is observed for $\mathrm{Ag} / \mathrm{Fe} / \mathrm{TiO} 2$ (Figure 2a,b). The histogram for $\mathrm{Ag} / \mathrm{Mg} / \mathrm{TiO}_{2}$ (Figure 2c) is broader, with an average size of $5.5 \mathrm{~nm}$. The range of particle sizes $\left(3-12 \mathrm{~nm}\right.$ ) of $\mathrm{Ag} / \mathrm{Ce} / \mathrm{TiO}_{2}$ (Figure $2 \mathrm{~d}$ ) is also broad and shifted to larger sizes compared to the other samples, with an average particle size of $7.2 \mathrm{~nm}$. HRTEM of the modified supports is presented in Figure $2 \mathrm{e}-\mathrm{g}$. For all studied supports, no contrasting particles related to modifiers were found on $\mathrm{TiO}_{2}$. Consequently, it can be inferred that modifiers are distributed homogeneously in the form of subnanometer species.

Table 1. Textural properties of supports and catalysts and analytical silver content of the catalysts treated in $\mathrm{H}_{2}$ at $300{ }^{\circ} \mathrm{C}$ for $1 \mathrm{~h}$.

\begin{tabular}{cccc}
\hline \multirow{2}{*}{ Samples } & \multicolumn{2}{c}{$\mathbf{S}_{\mathbf{B E T}}, \mathbf{~}^{\mathbf{2}} \mathbf{g}$} & EDX \\
\cline { 2 - 4 } & Support & Catalyst & Ag Content, wt \% \\
\hline $\mathrm{Ag} / \mathrm{Ce} / \mathrm{TiO}_{2}$ & 43.4 & 46.3 & $2.1 \pm 0.4$ \\
$\mathrm{Ag} / \mathrm{Fe} / \mathrm{TiO}_{2}$ & 45.5 & 44.0 & $1.9 \pm 0.4$ \\
$\mathrm{Ag} / \mathrm{Mg} / \mathrm{TiO}_{2}$ & 42.6 & 43.9 & $2.0 \pm 0.3$ \\
\hline
\end{tabular}




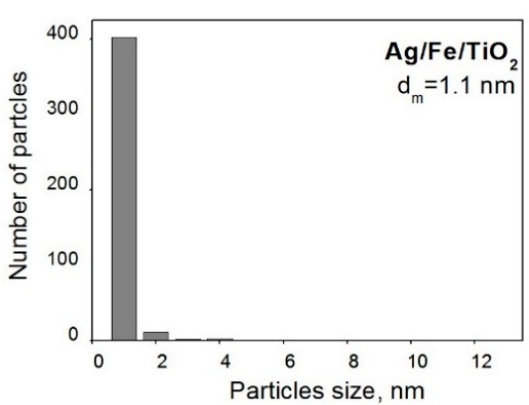

(a)

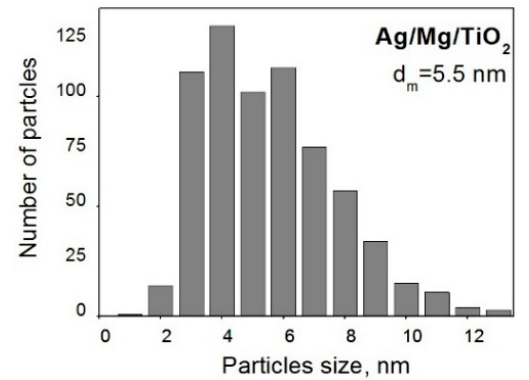

(c)

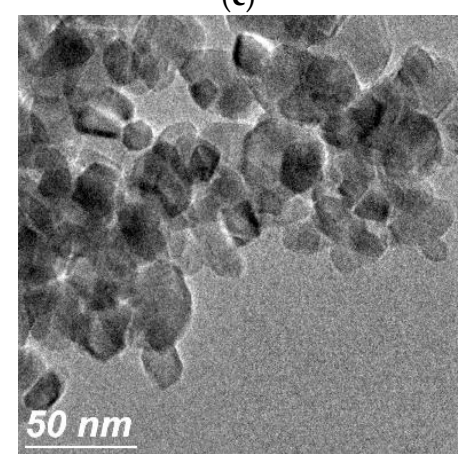

(e)

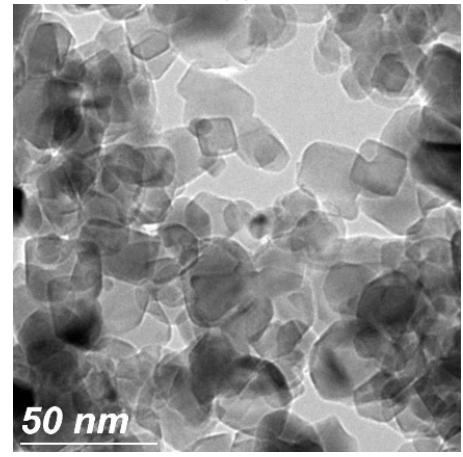

(g)

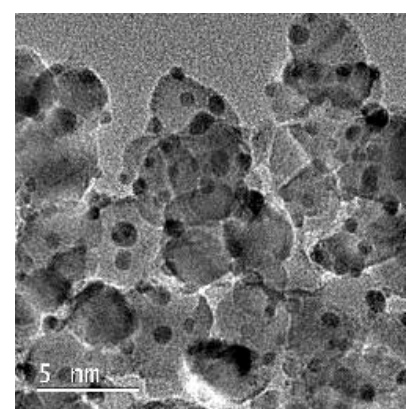

(b)

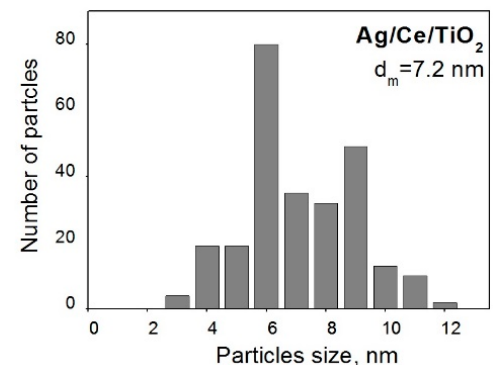

(d)

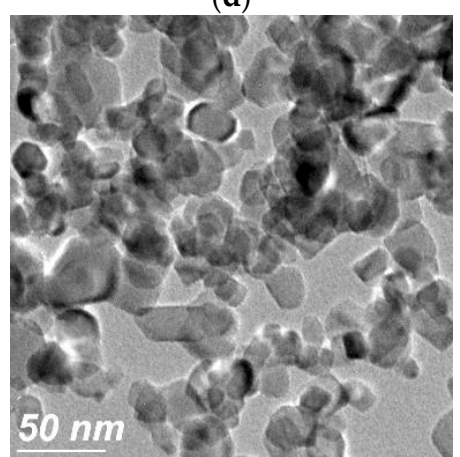

(f)

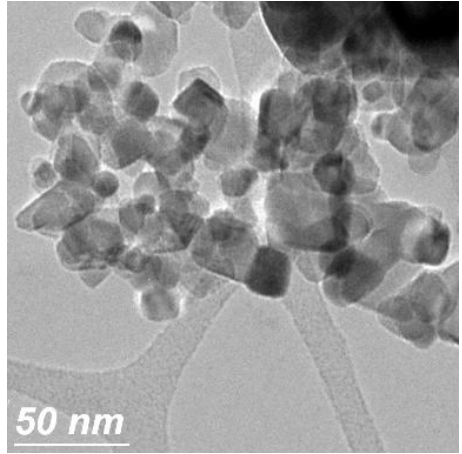

(h)

Figure 2. Particle size distribution of $\mathrm{Ag}$ catalysts supported on $\mathrm{Fe} / \mathrm{TiO}_{2}(\mathbf{a}) ; \mathrm{Mg} / \mathrm{TiO}_{2}$ (c) and $\mathrm{Ce} / \mathrm{TiO}_{2}$ (d) treated in $\mathrm{H}_{2}$ at $300{ }^{\circ} \mathrm{C}$ for $1 \mathrm{~h}$. Microphotographs of catalyst $\mathrm{Ag} / \mathrm{Fe} / \mathrm{TiO}_{2}$ (b) and supports: $\mathrm{Fe} / \mathrm{TiO}_{2}(\mathbf{e}) ; \mathrm{Mg} / \mathrm{TiO}_{2}(\mathbf{f}) ; \mathrm{Ce} / \mathrm{TiO}_{2}(\mathrm{~g})$ and $\mathrm{TiO}_{2}(\mathbf{h})$.

Figure 3 shows the diffraction lines for the modified supports and Ag catalysts. It can be seen that SR-XRD patterns are practically the same for modified supports and the corresponding Ag catalysts. For all catalysts, reflections corresponding to the crystalline silver phase were not detected in their SR-XRD patterns (Figure 3). This suggests that silver is either amorphous or that its crystallite size is below the SR-XRD detection limit $(2 \mathrm{~nm})$. These results confirm the HRTEM data for the Fe-modified samples: all particles in $\mathrm{Ag} / \mathrm{Fe} / \mathrm{TiO}_{2}$ has a size of $2 \mathrm{~nm}$ or less. 


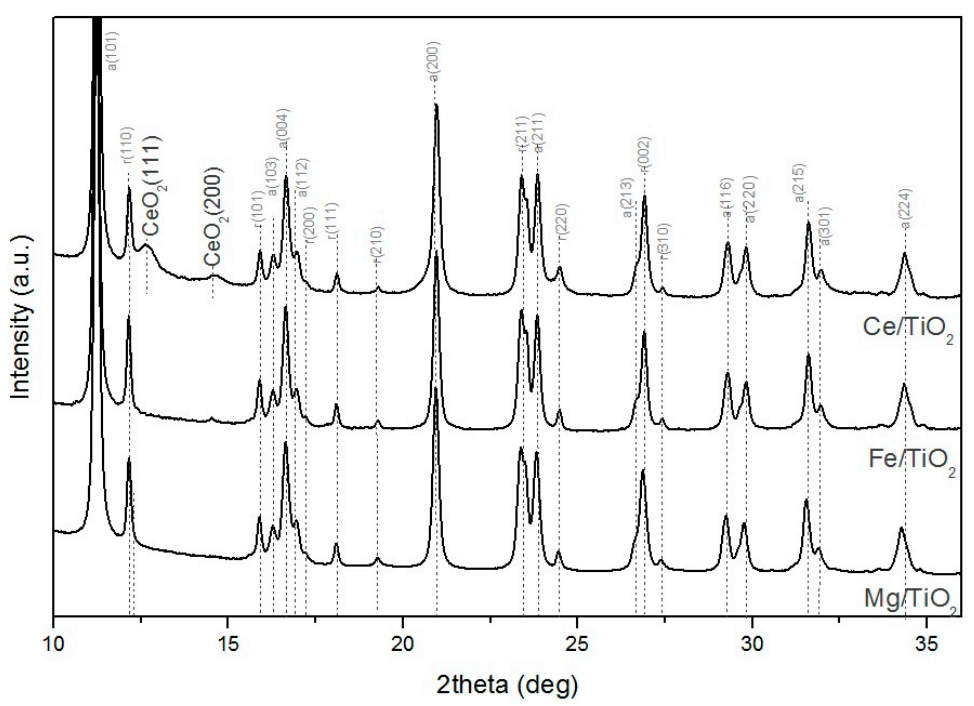

(a)

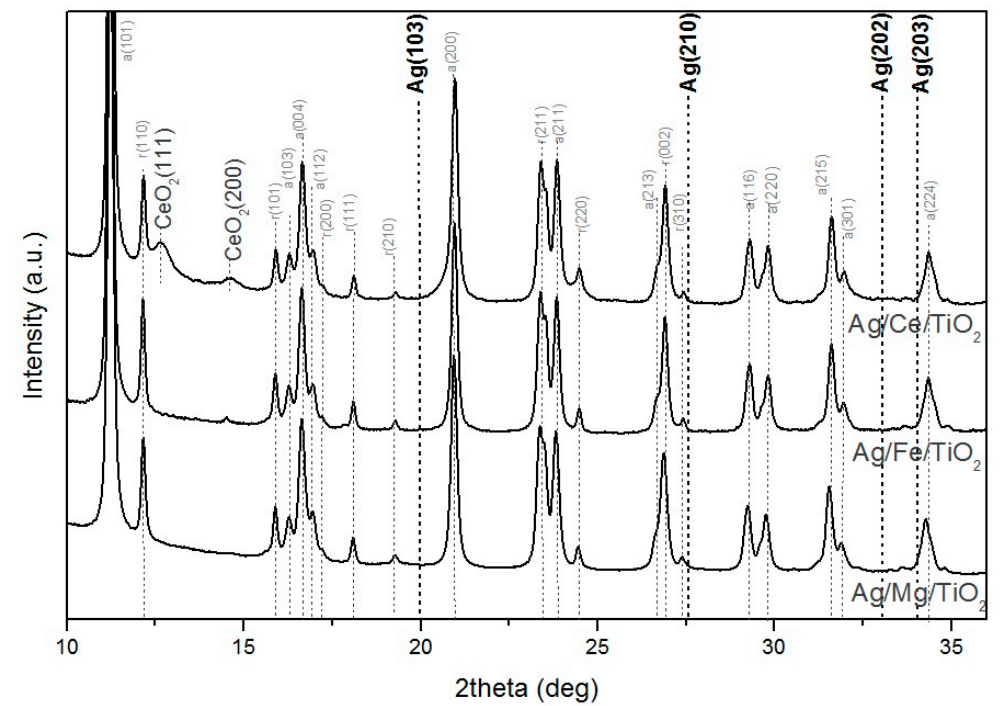

(b)

Figure 3. The SR-XRD patterns for the supports (a) and catalysts treated in $\mathrm{H}_{2}$ flow at $300{ }^{\circ} \mathrm{C}$ for $1 \mathrm{~h}$ (b).

As the particle sizes' range recorded by the HRTEM was 3-12 $\mathrm{nm}$, i.e., larger than the SR-XRD detection limit, one could expect silver phases in $\mathrm{Ag} / \mathrm{Ce} / \mathrm{TiO}_{2}$ to be detectable by SR-XRD; however, the diffraction lines for silver were absent. This indicates that the silver crystallites' size is $<2 \mathrm{~nm}$ and that the HRTEM histogram is representative of only a small part of the silver present in $\mathrm{Ag} / \mathrm{Ce} / \mathrm{TiO}$.

What could cause the formation of large particles in $\mathrm{Ag} / \mathrm{Ce} / \mathrm{TiO}_{2}$ is an interesting question. From low-magnification HRTEM micrograph and corresponding elemental maps in false colors for Ag and Ce extracted from the EDS data, it can be seen that silver in $\mathrm{Ag} / \mathrm{Ce} / \mathrm{TiO}_{2}$ corresponds to both large and small particles (Figure 4). Cerium is distributed over the surface quite uniformly, which is in agreement with the HRTEM of $\mathrm{Ce} / \mathrm{TiO}_{2}$. Elemental maps in false colors for $\mathrm{Ag}$ and Ce extracted from the EDS data and HRTEM of $\mathrm{Ce} / \mathrm{TiO}_{2}$ indicate the absence of large $\mathrm{CeO}_{2}$ particles. It allows attributing the $\mathrm{CeO}_{2}$ diffraction line of very low relative intensity (Figure 3) to $\sim 10-\mathrm{nm} \mathrm{CeO}_{2}$ crystallites, which represent only a small part of $\mathrm{CeO}_{2}$ total content. Hence, 3-12-nm particles of the HRTEM histogram of $\mathrm{Ag} / \mathrm{Ce} / \mathrm{TiO}_{2}$ correspond to $\mathrm{Ag}$ particles, not to $\mathrm{CeO}_{2}$ ones. Nevertheless, it should be taken into account that small silver particles were also registered by the EDS data. 

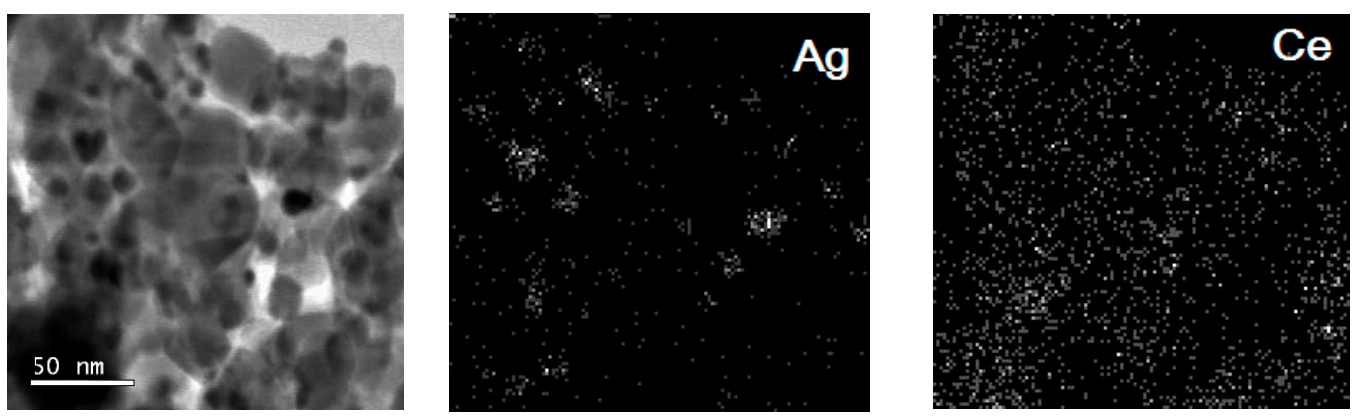

Figure 4. Low-magnification HRTEM micrograph and corresponding elemental maps in false colors for $\mathrm{Ag}$ and $\mathrm{Ce}$ extracted from the EDS data cube for $\mathrm{Ag} / \mathrm{Ce} / \mathrm{TiO}_{2}$ sample treated in $\mathrm{H}_{2}$ flow at $300{ }^{\circ} \mathrm{C}$ for $1 \mathrm{~h}$.

Figure 3 shows that the reflections corresponding to the modifier were only detected for $\mathrm{Ag} / \mathrm{Ce} / \mathrm{TiO}_{2}$. Despite the fact that the molar concentrations of the modifiers were the same in the three modified supports, the higher molecular weight of $\mathrm{CeO}_{2}$ resulted in a higher mass ratio, which exceeds the weight content of other additives and explains the appearance of the corresponding peaks. $\mathrm{CeO}_{2}$ is in the form of large particles ( $10 \mathrm{~nm}$, as estimated by the Scherrer method).

To confirm the hypothesis, based on SR-XRD results, of the presence of silver species with size $<1 \mathrm{~nm}$ in $\mathrm{Ag} / \mathrm{Ce} / \mathrm{TiO}_{2}$, we took advantage of a DRS method [41-44]. It provides an easy registration of silver clusters of $<1 \mathrm{~nm}$ by absorption bands around $260-290 \mathrm{~nm}, \mathrm{Ag}+$ cations at $250 \mathrm{~nm}$ and nanoparticles at about $400 \mathrm{~nm}$. Particles of 1-1.5 nm (quasi-metallic particles) are characterized by unstructured absorbance above $400 \mathrm{~nm}$. The absorption characteristic of these quasi-metallic species is similar to that of colloidal silver as a consequence of increasing particle size from atomic and molecular scales to the bulk metal one [45].

As can be seen in Figure 5, the intense absorption peaks of the support (200-300 nm) are observed in the same region as those of $\mathrm{Ag}$ cations and clusters for the catalysts. This hinders the application of this method for investigating these Ag species. Catalysts after $\mathrm{H}_{2}$ treatment exhibit the unstructured absorbance corresponding to quasi-metallic silver particles with a size of about 1-1.5 nm. As no significant differences were observed in the visible range of the spectra of all catalysts, it can be concluded that the differences in activity after $\mathrm{H}_{2}$ pretreatments are not caused by quasi-metallic silver particles with a size of about 1-1.5 nm. DRS results (as SR-XRD) also indicate that in all samples, most of the Ag is in the form of species with size $<1.5 \mathrm{~nm}$. The large contribution of Ag species with size $<1.5 \mathrm{~nm}$ in the three catalysts, measured by DRS, is in good agreement with the HRTEM histogram for $\mathrm{Ag} / \mathrm{Fe} / \mathrm{TiO}_{2}$ (Figure 2a). However, for $\mathrm{Ag} / \mathrm{Ce} / \mathrm{TiO}_{2}$ and $\mathrm{Ag} / \mathrm{Mg} / \mathrm{TiO}_{2}$, these DRS data show that their HRTEM histograms represent only part of the actual sizes distributions, and they do not include Ag species $<1.5 \mathrm{~nm}$.

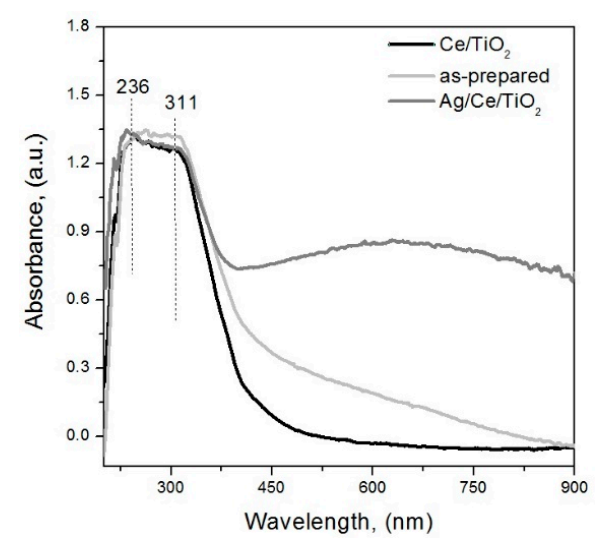

(a)

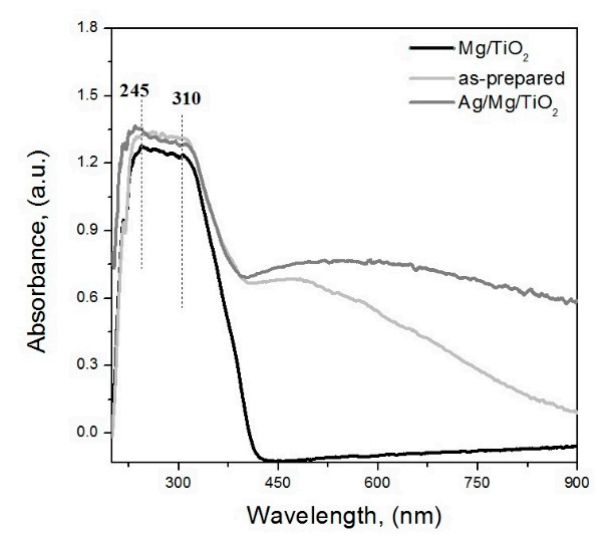

(b)

Figure 5. Cont. 


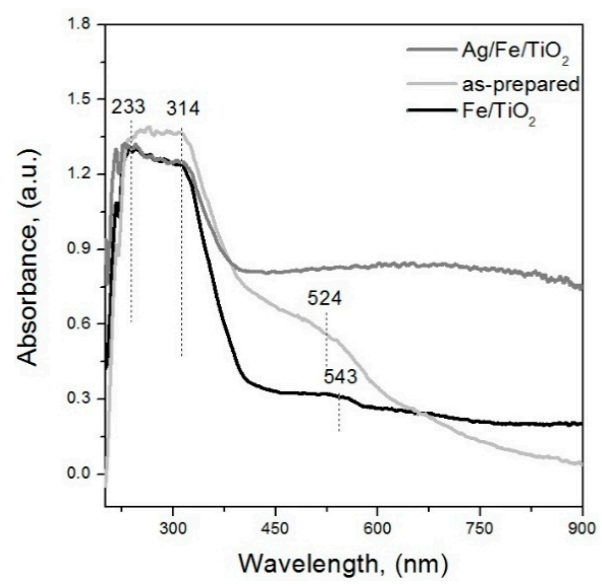

(c)

Figure 5. DRS of the supports based on $\mathrm{TiO}_{2}$, modified with $\mathrm{Ce}(\mathbf{a}) ; \mathrm{Mg}(\mathbf{b})$ or $\mathrm{Fe}(\mathbf{c})$ oxides and their corresponding catalysts before (as-prepared) and after reduction in $\mathrm{H}_{2}$ under $300{ }^{\circ} \mathrm{C}$ for $1 \mathrm{~h}$.

XPS spectra of the Ag 3d5/2 lines of the catalysts are presented in Figure 6. Ag 3d5/2 peaks required deconvolution for all samples, because their widths exceed those corresponding to a single state. Table 2 shows that most silver $(80 \%)$ in $\mathrm{Ag} / \mathrm{Ce} / \mathrm{TiO}_{2}$ is in cationic form $(\mathrm{BE}=365.7 \mathrm{eV}$ [46-48]), while in $\mathrm{Ag} / \mathrm{Fe} / \mathrm{TiO}_{2}$, its contribution is $14 \%$, and in $\mathrm{Ag} / \mathrm{Mg} / \mathrm{TiO}_{2}$, cationic silver was not registered. Supports modified with $\mathrm{Ce}$ and Fe oxides are able to stabilize cationic silver, because these additives exhibit electron-acceptor properties, while Mg oxide is electron-donor [29,44,49,50]. Furthermore, note that ceria nanoparticles are able to provide oxygen dissociation, pointing out differences between $\mathrm{Ag} / \mathrm{Ce} / \mathrm{TiO}_{2}$ and $\mathrm{Ag} / \mathrm{Fe} / \mathrm{TiO}_{2}$ regarding their catalytic properties [36,51,52].

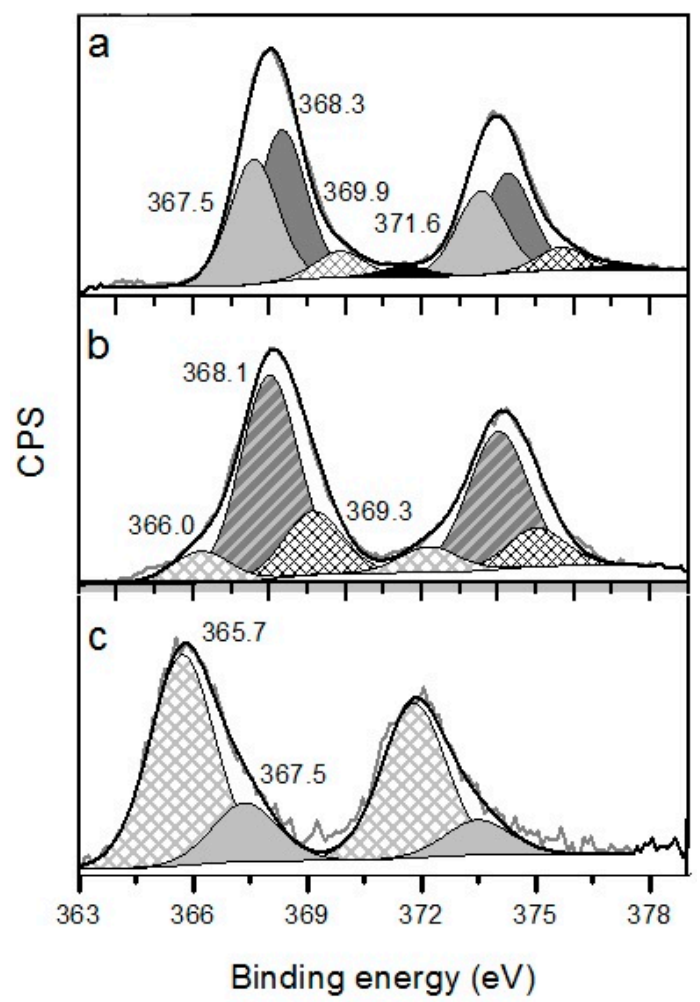

Figure 6. XPS of lines $\mathrm{Ag} 3 \mathrm{~d} 5 / 2$ for $\mathrm{Ag}$ catalysts supported on $\mathrm{Mg} / \mathrm{TiO}_{2}$ (a); $\mathrm{Fe} / \mathrm{TiO}_{2}(\mathbf{b})$ and $\mathrm{Ce} / \mathrm{TiO}_{2}$ (c) after reduction in $\mathrm{H} 2$ at $300{ }^{\circ} \mathrm{C}$ for $1 \mathrm{~h}$. 
Table 2. Binding energy and relative atomic concentrations of various silver electronic states in catalysts.

\begin{tabular}{|c|c|c|c|c|}
\hline \multirow{2}{*}{ Catalysts } & \multicolumn{4}{|c|}{$\begin{array}{l}\text { BE of Different gold Electronic States }(\mathrm{eV}) \text { and Their Relative } \\
\text { Atomic Concretions, \% (Indicated in Parenthesis) }\end{array}$} \\
\hline & $\begin{array}{c}\mathrm{Ag}^{+} \\
364.0-366.2\end{array}$ & $\underset{367.4-368.1}{\mathrm{Ag}_{2} \mathrm{O}}$ & $\begin{array}{l}\mathrm{Ag}^{\circ} \\
368.1-368.4\end{array}$ & $\begin{array}{l}\mathrm{Ag}<2 \mathrm{~nm} \\
>369.0\end{array}$ \\
\hline $\mathrm{Ag} / \mathrm{Mg} / \mathrm{TiO}_{2}$ & - & $367.5(47 \%)$ & $368.3(40 \%)$ & $369.9(9 \%), 371.6(4 \%)$ \\
\hline $\mathrm{Ag} / \mathrm{Fe} / \mathrm{TiO}_{2}$ & $366.0(14 \%)$ & \multicolumn{2}{|c|}{$368.1(65 \%)$} & $369.3(21 \%)$ \\
\hline $\mathrm{Ag} / \mathrm{Ce} / \mathrm{TiO}_{2}$ & $365.7(80 \%)$ & $367.5(20 \%)$ & - & - \\
\hline
\end{tabular}

XPS results indicate that the extent of strong metal-support interaction (SMSI) for Ag follows the trend: $\mathrm{Ag} / \mathrm{Ce} / \mathrm{TiO}_{2}>\mathrm{Ag} / \mathrm{Fe} / \mathrm{TiO}_{2}>\mathrm{Ag} / \mathrm{Mg} / \mathrm{TiO}_{2}$. The nature of SMSI for Ag species is discussed in more detail below. It should be noted that the initial $\mathrm{TiO}_{2}$ support is a mixture of two phases: rutile and anatase. Figure 7 shows that all of the lattice constants of both phases, obtained from the EXAFS data, of the initial $\mathrm{TiO}_{2}$ decreased when modifiers were added. Taking into account the low modifier content $(<6 \mathrm{wt} \%)$, one may conclude that modifiers are quite uniformly distributed throughout the $\mathrm{TiO}_{2}$ structure and that they strongly interact with $\mathrm{TiO}_{2}$. EXAFS results also showed that the rutile phase contribution increased $4 \%, 5 \%$ and $6 \%$ after modification with $\mathrm{Ce}, \mathrm{Fe}$ and $\mathrm{Mg}$ oxide, respectively. The change of the rutile/anatase ratio (bulk properties) after modification is known to occur [53]. Details of the discussion of the influence of modification on the rutile/anatase ratio and lattice constants exceed the allocated extension of this paper and will be published elsewhere.

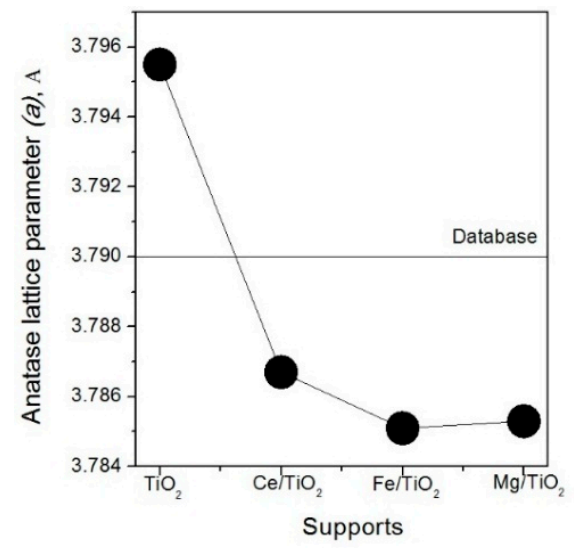

(a)

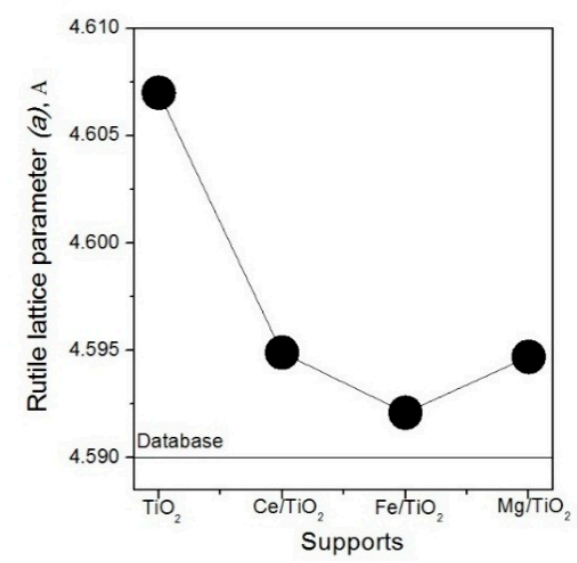

(c)

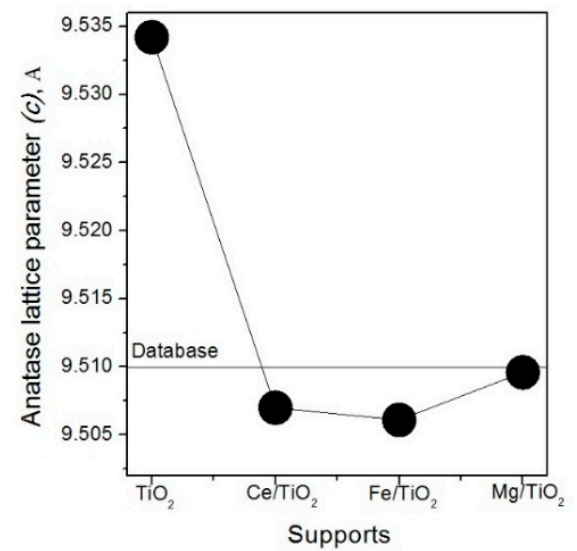

(b)

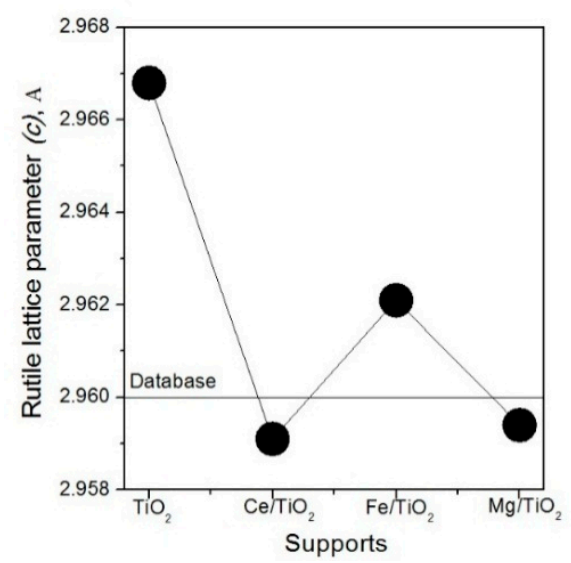

(d)

Figure 7. Lattice constants of anatase $(\mathbf{a}, \mathbf{b})$ and rutile $(\mathbf{c}, \mathbf{d})$ calculated on the basis of EXAFS data for the studied supports. 
The XPS study of various forms of oxygen and carbon showed differences in the number and contribution of oxygen and carbon surface states on the modified supports (Figure 8a,c). While for $\mathrm{TiO}_{2}, \mathrm{Mg} / \mathrm{TiO}_{2}$ and $\mathrm{Ce} / \mathrm{TiO}_{2}$, very similar $\mathrm{C} 1$ s and $\mathrm{O} 1$ s profiles, for $\mathrm{Ag} / \mathrm{Fe} / \mathrm{TiO}_{2}$, a big change in both is observed, indicating a strong interaction of iron oxide with the original support. Hence, the interaction modifier- $\mathrm{TiO}_{2}$ is the strongest for $\mathrm{Ag} / \mathrm{Fe} / \mathrm{TiO}_{2}$.

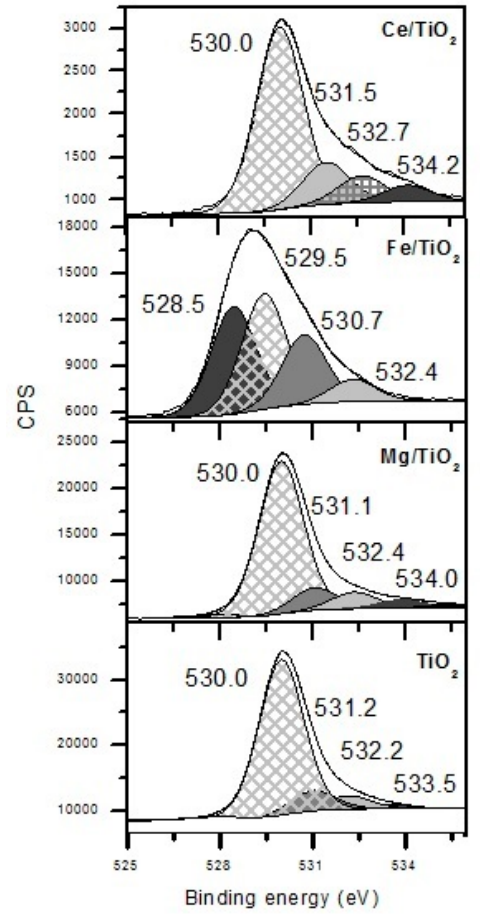

(a)

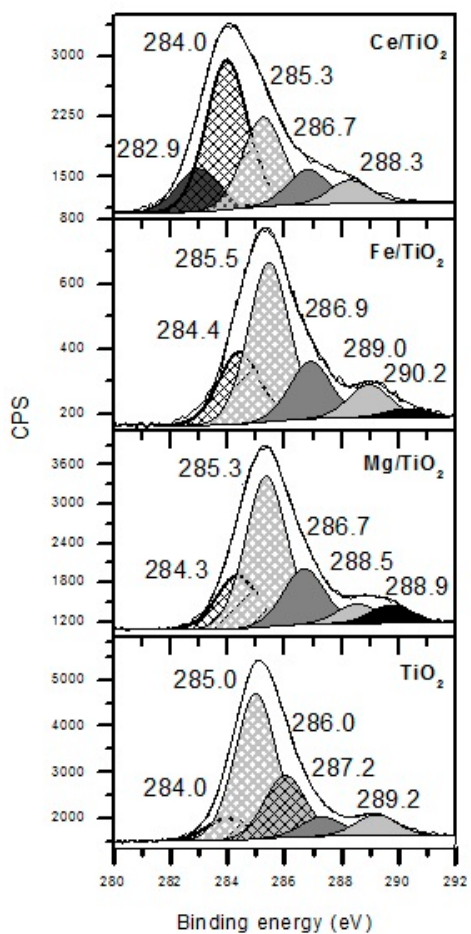

(c)

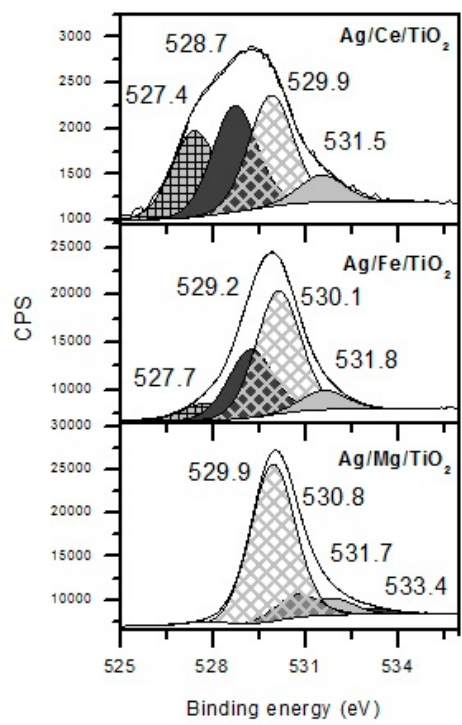

(b)

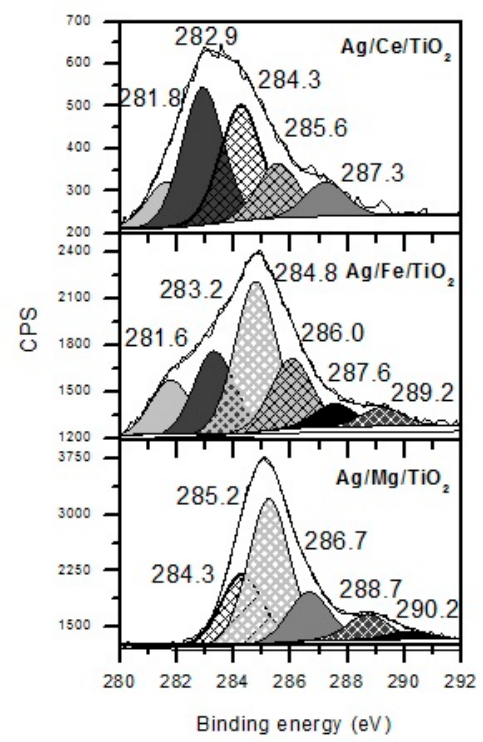

(d)

Figure 8. XPS lines of O1s $(\mathbf{a}, \mathbf{b})$ and $\mathrm{C} 1 \mathrm{~s}(\mathbf{c}, \mathbf{d})$ for supports $(\mathbf{a}, \mathbf{c})$ and Ag catalysts after reduction in $\mathrm{H}_{2}$ at $300{ }^{\circ} \mathrm{C}$ for $1 \mathrm{~h}(\mathbf{b}, \mathbf{d})$. 
Silver addition caused redistribution of oxygen and carbon states (Figure $8 \mathrm{~b}, \mathrm{~d}$ ). New peaks of $\mathrm{C} 1 \mathrm{~s}$ and $\mathrm{O} 1 \mathrm{~s}$ with a significant contribution appeared for $\mathrm{Ag} / \mathrm{Ce} / \mathrm{TiO}_{2}$ and $\mathrm{Ag} / \mathrm{Fe} / \mathrm{TiO}$, while for $\mathrm{Ag} / \mathrm{Mg} / \mathrm{TiO}_{2}$, minimal changes of the investigated surface states are observed compared to $\mathrm{TiO}_{2}$ and $\mathrm{Mg} / \mathrm{TiO}_{2}$. This proves the SMSI in the $\mathrm{Ag} / \mathrm{Ce} / \mathrm{TiO}_{2}$ and $\mathrm{Ag} / \mathrm{Fe} / \mathrm{TiO}_{2}$ catalysts and a weaker interaction in $\mathrm{Ag} / \mathrm{Mg} / \mathrm{TiO}_{2}$. This can be the reason for the formation of small quasi-metallic silver particles with a size of $1 \mathrm{~nm}$ on $\mathrm{Fe} / \mathrm{TiO}_{2}$ and even smaller subnanometer silver species on $\mathrm{Ce} / \mathrm{TiO}$.

The results of XANES and EXAFS methods for the studied catalysts and reference compounds (metallic silver and bulk silver oxide) are presented in Figure 9, and their evaluation is in Table 3. For these methods, we focus our attention on analyzing the results for $\mathrm{Ag} / \mathrm{Fe} / \mathrm{TiO}_{2}$ and $\mathrm{Ag} / \mathrm{Mg} / \mathrm{TiO}$. Data for $\mathrm{Ag} / \mathrm{Ce} / \mathrm{TiO}_{2}$ were not analyzed, because XPS data (Table 2) showed that $80 \%$ of $\mathrm{Ag}$ is in the cationic form, not registered by XANES and EXAFS methods. $\mathrm{Ag}_{2} \mathrm{O}$ species with coordination numbers 2.5 and 2.6 were detected for $\mathrm{Ag} / \mathrm{Fe} / \mathrm{TiO}_{2}$ and $\mathrm{Ag} / \mathrm{Mg} / \mathrm{TiO}_{2}$, respectively. This indicates that $\mathrm{Ag}_{2} \mathrm{O}$ species are very small. Their contribution is higher in $\mathrm{Ag} / \mathrm{Mg} / \mathrm{TiO}_{2}(90 \mathrm{~mol} \%)$ compared to $\mathrm{Ag} / \mathrm{Fe} / \mathrm{TiO}_{2}(62 \mathrm{~mol} \%)$. Consequently, there are smaller particles in $\mathrm{Ag} / \mathrm{Mg} / \mathrm{TiO}_{2}$. The $\mathrm{Ag} / \mathrm{Fe} / \mathrm{TiO} 2$ sample contains more metallic particles characterized by a significantly higher coordination number (five), which is closer to that of bulk metal (12) than that for $\mathrm{Ag} / \mathrm{Mg} / \mathrm{TiO}_{2}$ (2.2).

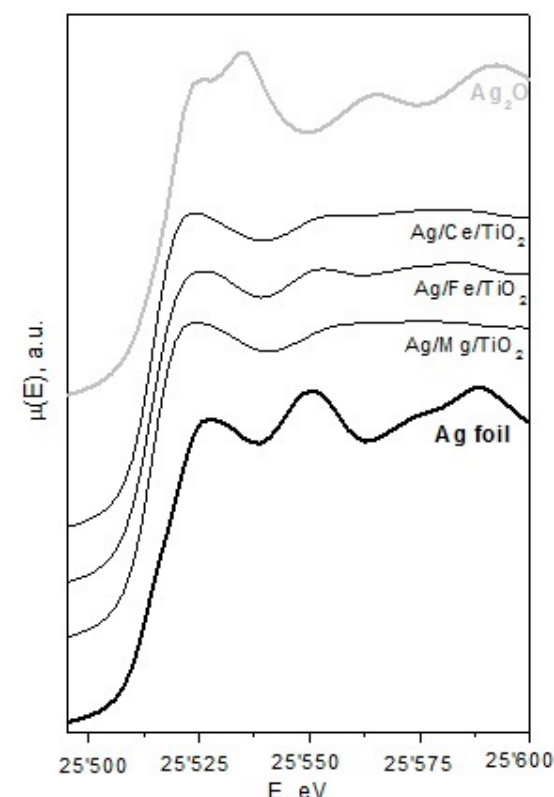

(a)

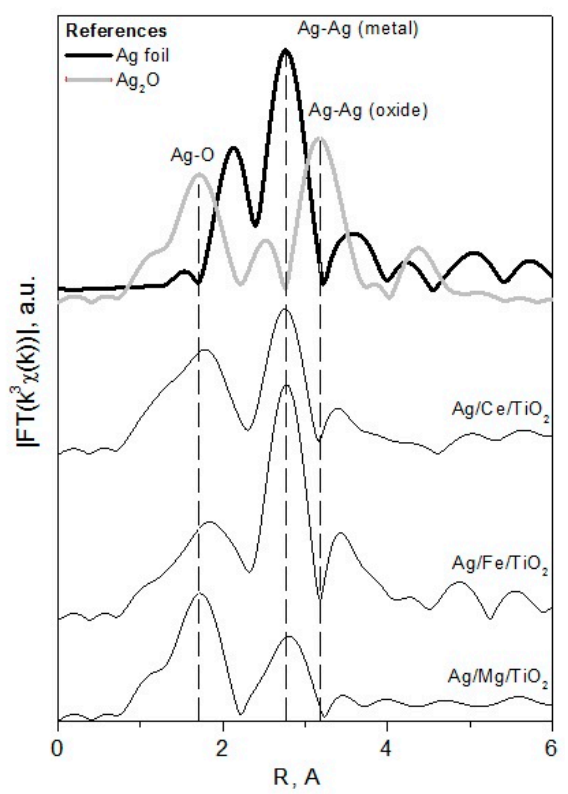

(b)

Figure 9. XANES (a) and EXAFS (b) spectra of catalysts treated in $\mathrm{H}_{2}$ flow at $300^{\circ} \mathrm{C}$ for $1 \mathrm{~h}$.

Table 3. Sample composition and structural parameters obtained from XAFS spectroscopies data.

\begin{tabular}{ccccccc}
\hline \multirow{2}{*}{ Sample } & \multicolumn{5}{c}{ XANES } & \multicolumn{3}{c}{ EXAFS } \\
\cline { 2 - 7 } & Phase & $\begin{array}{c}\text { Molar } \\
\text { Fraction, } \%\end{array}$ & $\begin{array}{c}\text { R-Factor, } \\
\%\end{array}$ & $\begin{array}{c}\text { Corresponding } \\
\text { Single-Scattering Path }\end{array}$ & $\begin{array}{c}\text { Coordination } \\
\text { Number }\end{array}$ & $\begin{array}{c}\text { Mean Squared } \\
\text { Displacement }\end{array}$ \\
\hline $\mathrm{Ag}$ foil & $\mathrm{Ag}$ & 100 & - & $\mathrm{Ag}-\mathrm{Ag}$ & 12 & 0.0097 \\
\hline $\mathrm{Ag}_{2} \mathrm{O}$ & $\mathrm{Ag}_{2} \mathrm{O}$ & 100 & - & $\mathrm{Ag}-\mathrm{O}$ & 4 & - \\
\hline \multirow{2}{*}{$\mathrm{Ag} / \mathrm{Ce} / \mathrm{TiO}_{2}$} & $\mathrm{Ag}$ & 26.4 & 0.030 & $\mathrm{Ag}-\mathrm{Ag}$ & 2.7 & 0.0115 \\
& $\mathrm{Ag} 2 \mathrm{O}$ & 73.6 & $\mathrm{Ag}-\mathrm{O}$ & 3.5 & 0.0183 \\
\hline \multirow{2}{*}{$\mathrm{Ag} / \mathrm{Mg} / \mathrm{TiO}_{2}$} & $\mathrm{Ag}$ & 9.8 & 0.024 & $\mathrm{Ag}-\mathrm{Ag}$ & 2.2 & 0.0149 \\
& $\mathrm{Ag}_{2} \mathrm{O}$ & 90.2 & $\mathrm{Ag}-\mathrm{O}$ & 2.6 & 0.0127 \\
\hline \multirow{2}{*}{$\mathrm{Ag} / \mathrm{Fe} / \mathrm{TiO}_{2}$} & $\mathrm{Ag}$ & 38.3 & 0.025 & $\mathrm{Ag}-\mathrm{Ag}$ & 5.0 & 0.0131 \\
& $\mathrm{Ag}_{2} \mathrm{O}$ & 61.7 & $\mathrm{Ag}-\mathrm{O}$ & 2.5 & 0.0170 \\
\hline
\end{tabular}


This evidences that metallic particles in $\mathrm{Ag} / \mathrm{Mg} / \mathrm{TiO}_{2}$ are smaller than in $\mathrm{Ag} / \mathrm{Fe} / \mathrm{TiO}_{2}$, which is again in contradiction to HRTEM data (Figure 2). This in turn indicates that Ag species of less than $1 \mathrm{~nm}$ do exist in $\mathrm{Ag} / \mathrm{Mg} / \mathrm{TiO}_{2}$, but they were not registered by HRTEM. These species can include cations (as shown by XPS data), as well as metallic and oxide clusters (as evidenced from XPS, XANES and EXAFS data). Coordination numbers from EXAFS data indicate that the silver particle sizes in $\mathrm{Ag} / \mathrm{Ce} / \mathrm{TiO}_{2}$ and $\mathrm{Ag} / \mathrm{Mg} / \mathrm{TiO}_{2}$ are similar, whereas those in $\mathrm{Ag} / \mathrm{Fe} / \mathrm{TiO}_{2}$ are larger. This is in agreement with DRS, SR-XRD and XPS data. Hence, the analysis of the results of all applied methods showed that HRTEM histograms of $\mathrm{Ag} / \mathrm{Ce} / \mathrm{TiO}_{2}$ and $\mathrm{Ag} / \mathrm{Mg} / \mathrm{TiO}_{2}$ only reflect part of the $\mathrm{Ag}$ particles, those are excluding subnanometer $\mathrm{Ag}$ species.

Turning back to XPS data, it is worthy to note that the position of the Ag 3d5/2 peak for $\mathrm{Ag} / \mathrm{Fe} / \mathrm{TiO}_{2}(368.1 \mathrm{eV})$ is on the limit of the typical positions for $\mathrm{Ag}_{2} \mathrm{O}$ and $\mathrm{Ag}^{0}$. Probably, this $\mathrm{Ag} 3 \mathrm{~d} 5 / 2$ peak is typical for $1 \mathrm{~nm}$ Ag quasi-metallic particles, which composes the main part of this sample. We did not find in the literature data for Ag 3d5/2 BE for 1-nm Ag quasi-metallic particles. Therefore, probably, our data can be considered as some of the first ones for their characterization. The interpretation of the peaks below $369 \mathrm{eV}$ observed for $\mathrm{Ag} / \mathrm{Fe} / \mathrm{TiO}{ }_{2}$ and $\mathrm{Ag} / \mathrm{Mg} / \mathrm{TiO}_{2}$ is also difficult, because this BE interval is not well identified in the literature. Kim's group [54,55] suggested that this interval is characteristic for Ag clusters with size $<2 \mathrm{~nm}$ supported on highly ordered pyrolytic graphite. Thus, $\mathrm{Ag} / \mathrm{Fe} / \mathrm{TiO}_{2}$ contains mainly quasi-metallic $\mathrm{Ag}$ particles of $1 \mathrm{~nm}$, those $<2 \mathrm{~nm} \mathrm{Ag}$ clusters and a small contribution of silver cations. Thus, for this catalyst, HRTEM and XPS data are in good agreement. Spectra of $\mathrm{Ag} / \mathrm{Mg} / \mathrm{TiO}_{2}$ can be interpreted as composed by $\mathrm{Ag}^{0}(\mathrm{BE}=368.3 \mathrm{eV}$ [48]), $\mathrm{Ag}_{2} \mathrm{O}(\mathrm{BE}=367.5 \mathrm{eV}$ [48] $)$ and clusters with a size $<2 \mathrm{~nm}$. XPS data showed that $80 \%$ of surface silver is in the Ag+ state. This is in good agreement with HRTEM of Ce/TiO ${ }_{2}, \mathrm{EDS}, \mathrm{DRS}$ and SR-XRD.

Oxidized silver states were observed for all catalysts. This confirms the effective interaction of silver with supports. As Fe and Ce oxides exhibit electron-acceptor properties, while $\mathrm{Mg}$ oxide has electron-donor ones, their interaction with silver can modify its oxidation state. For $\mathrm{Ag} / \mathrm{Mg} / \mathrm{TiO}_{2}$, the transfer of electron density from $\mathrm{Mg}$ oxide to silver occurs with stabilization of $52 \%$ of silver in the reduced state, and the contribution from $\mathrm{Ag}+$ is not detected. In contrast, in $\mathrm{Ag} / \mathrm{Ce} / \mathrm{TiO}_{2}, 80 \%$ of surface silver is stabilized as $\mathrm{Ag}+\mathrm{Ag} / \mathrm{Fe} / \mathrm{TiO}_{2}$ is an intermediate case; only $14 \%$ of silver is in the form of $\mathrm{Ag}+$ cations. In $\mathrm{Ag} / \mathrm{Ce} / \mathrm{TiO}_{2}$ catalyst, $100 \%$ of the surface silver is in oxidized states. These results confirm that the $\mathrm{HRTEM} \mathrm{Ag} / \mathrm{Ce} / \mathrm{TiO}_{2}$ histogram (Figure $2 \mathrm{~d}$ ) corresponds only to a small part of silver particles.

Catalysts' investigation by these physicochemical methods showed that, firstly, the HRTEM histogram for $\mathrm{Ag} / \mathrm{Fe} / \mathrm{TiO}_{2}$ (Figure 2) is the most exact, while for $\mathrm{Ag} / \mathrm{Mg} / \mathrm{TiO}_{2}$ and $\mathrm{Ag} / \mathrm{Ce} / \mathrm{TiO}_{2}$, besides Ag nanoparticles with sizes from 1-12 nm, Ag species with size $<1 \mathrm{~nm}$, non-visible in HRTEM, exist. Thus, the majority of $\mathrm{Ag}$ species in all samples has sizes $\leqslant 1 \mathrm{~nm}$. Secondly, the strength of interaction between $\mathrm{Ag}$ and support decreases as follows: $\mathrm{Ag} / \mathrm{Ce} / \mathrm{TiO}_{2}>\mathrm{Ag} / \mathrm{Fe} / \mathrm{TiO}_{2}>\mathrm{Ag} / \mathrm{Mg} / \mathrm{TiO}_{2}$.

The majority of $\mathrm{Ag}$ species in all samples have size $\leqslant 1 \mathrm{~nm}$; consequently, differences in the catalytic activity cannot be explained by differences in Ag species size, but can be caused by the difference in the SMSI. For $\mathrm{Ag} / \mathrm{Ce} / \mathrm{TiO}_{2}$, the activity was very stable for all pretreatments (Figure 1 ). This can be explained by the fact that this sample has the most SMSI. On the contrary, for $\mathrm{Ag} / \mathrm{Mg} / \mathrm{TiO}_{2}$, activity was very sensitive to the type of pretreatment. This can be due to the weak interaction of $\mathrm{Ag}$ species with support. The behavior of $\mathrm{Ag} / \mathrm{Fe} / \mathrm{TiO}_{2}$ presents an intermediate case as far as catalytic activity and SMSI are concerned.

The existence of small silver species, active for an industrially-important reaction, such as CO oxidation, has been suggested in other works [1,28]. In this work, Ag subnanometer species in $\mathrm{Ag} / \mathrm{Mg} / \mathrm{TiO}_{2}$ and $\mathrm{Ag} / \mathrm{Ce} / \mathrm{TiO}_{2}$ catalysts were for the first time detected and then characterized by using several physicochemical techniques. The catalytic performance can actually be enhanced if deactivation of subnanometer silver species, that are active at low temperatures, is prevented. This prevention can be done by increasing of SMSI by way of selecting the type of modifier and improving its distribution on the support surface. 
This work represents the continuation of studies where catalytic properties of silver catalysts could not be explained by particle size distributions measured by HRTEM and are explained by existence of small silver species. Works dedicated to this matter are very few; we found only four publications [12-15]. Below, we briefly describe them.

Undetected small silver clusters have been suggested as the source of specific catalytic properties [1-4]. Flytzani-Stephanopoulos et al. [33] explained the catalytic properties in the reduction of NO with methane by the coexistence of highly dispersed clusters $(<2 \mathrm{~nm})$ of oxidized silver and embedded $\mathrm{Ag}$ ions, which are active in selective reduction of $\mathrm{CH}_{4}$, but low active in $\mathrm{CH}_{4}$ combustion. The presence of small clusters was detected by the absorption band at $350 \mathrm{~nm}$, typical for $\mathrm{Ag}_{\mathrm{n}}{ }^{\delta+}$ in diffuse reflectance UV spectra. The unusual behavior of silver on $\mathrm{SiO}_{2}$ catalysts was observed after oxidizing and reducing pretreatments in $\mathrm{CO}$ oxidation [28]. During reduction in $\mathrm{H}_{2}$ at $100-300{ }^{\circ} \mathrm{C}$, oxidized silver species were redispersed, leading to the remarkable activity in CO oxidation. The existence of small silver species was detected by the FTIR of adsorbed CO [28]. It was shown that silver species could not be completely reduced to the metallic state, even after reduction by $\mathrm{H}_{2}$ at $500{ }^{\circ} \mathrm{C}$.

The present work shows deep insights into the existence of $\mathrm{Ag}$ species with size $\leqslant 1 \mathrm{~nm}$, non-detectable in HRTEM, as in the works previously mentioned. Combination of HRTEM, SR-XRD, DRS, XPS, EXAFS and XANES methods allowed us to detect and characterize these Ag species and to estimate the strength of their interaction with supports. These results led to concluding that the sensitivity of $\mathrm{CO}$ oxidation catalysts to pretreatments depends on the strength of the interaction of Ag species with supports. The combination of these methods can be used not only for detection and characterization of subnanometer metallic species in catalysts, but also for other materials used in various fields, such as sensors [56].

Activation-deactivation of the active component after different pretreatments can be caused by many factors, such as encapsulation, agglomeration, redispersion, carbonization, reduction-oxidation, etc. In the case of small particles, in addition to these factors, deactivation due to SMSI that is not strong enough should not be forgotten.

Under conditions that favor the formation of small supported species (say, high specific surface areas of supports, low metal concentration and active supports), the particle size distribution obtained from HRTEM results can be apparent, in other words, not correct. They can represent only part (in some cases, an extremely low part [29]) of all of the supported metal, because HRTEM registers particles $\geqslant 1 \mathrm{~nm}$ and does not register those ones with size $<1 \mathrm{~nm}$. Analysis and discussions of catalytic data taking into account these histograms can lead to the wrong conclusions. With the more widespread application of ac-HAADF/STEM to identify subnanometer species, it is expected that soon, this technique will become a routine procedure. At the moment, only a few researchers use this method for catalyst characterization. However, even in the case of the application ac-HAADF/STEM, its combined use with XPS, DRS and EXAFS is still much recommended, because they allow measuring a relatively big amount of the material and provide average characteristics, while ac-HAADF/STEM can be non-representative, especially for samples with an inhomogeneous component distribution. Moreover, complimentary information about charge, oxidation state, etc., obtained by these techniques would be enriching.

This work is one of the few paying attention to the problem of the identification and characterization of subnanometer species undetectable by HRTEM. This phenomenon should take the adequate place in nanoscience.

\section{Materials and Methods}

\subsection{Catalysts Preparation}

Titania Degussa P25 (Evonik's Chemicals Business Area, Essen, Germany) was used as the support $\left(45 \mathrm{~m}^{2} \cdot \mathrm{g}^{-1}\right.$, nonporous, $70 \%$ anatase and $30 \%$ rutile, purity $\left.>99.5 \%\right)$. Before preparation, titania was dried in air at $100{ }^{\circ} \mathrm{C}$ for at least $24 \mathrm{~h}$. Modification of titania with a molar ratio Ti/modifier $=40$ was 
made by impregnation $\left(2.5 \mathrm{~cm}^{3} / \mathrm{g}\right)$ of initial $\mathrm{TiO}_{2}$ with aqueous solutions of modifier (M) precursors, $\mathrm{Ce}\left(\mathrm{NO}_{3}\right)_{3} \cdot 6 \mathrm{H}_{2} \mathrm{O}, \mathrm{Fe}\left(\mathrm{NO}_{3}\right)_{3} \cdot 9 \mathrm{H}_{2} \mathrm{O}$ and $\mathrm{Mg}\left(\mathrm{NO}_{3}\right)_{2}$, from Aldrich (Aldrich, St. Louis, MO, USA). Impregnated supports were dried at room temperature for $48 \mathrm{~h}$ and then at $110{ }^{\circ} \mathrm{C}$ for $4 \mathrm{~h}$ and finally calcined at $550{ }^{\circ} \mathrm{C}$ for $4 \mathrm{~h}$.

Commercial $\mathrm{AgNO}_{3}$ from Aldrich was used as the silver precursor. Catalysts $\mathrm{Ag} / \mathrm{M} / \mathrm{TiO}_{2}$ with $2.2 \mathrm{wt} \% \mathrm{Ag}$ nominal loading were prepared by deposition precipitation with $\mathrm{NaOH}$ in the absence of light following the previously-reported procedure [57-59].

\subsection{Catalytic Tests}

For catalytic $\mathrm{CO}$ oxidation measurements, $0.5 \mathrm{~g}$ of the catalyst were packed in a quartz flow reactor. A first run of reaction was accomplished with as-prepared samples. Then, catalysts were cooled down in a reaction mixture, and then, the second run was performed. Alternatively, pretreatments in hydrogen or oxygen flow $(30 \mathrm{~mL} / \mathrm{min})$ at $300{ }^{\circ} \mathrm{C}$ for $1 \mathrm{~h}$ were applied to the catalyst prior to the test. The catalytic reaction was conducted with a $200-\mathrm{mL} / \mathrm{min}$ flow rate of the reactant gas mixture $1 \%$ vol. $\mathrm{O}_{2}, 1 \%$ vol. $\mathrm{CO}$ in Ar and with temperature increase from $30-305{ }^{\circ} \mathrm{C}$ in $15^{\circ} \mathrm{C}$ steps every $20 \mathrm{~min}$. The products were analyzed by gas chromatograph CHROMOS GC-1000, equipped with a TCD, and using two separate packed columns filled with CaA (to analyze oxygen and hydrogen) and AG-3 sorbent (to analyze both carbon oxides), respectively, and $\mathrm{He}$ as the carrier gas.

\subsection{Samples' Characterization}

Catalysts, either as-prepared or pretreated in hydrogen at $300{ }^{\circ} \mathrm{C}$ for $1 \mathrm{~h}$, were studied by diffuse reflectance UV-VIS spectroscopy (DRS) with a CARY 300 SCAN (Varian, Palo Alto, CA, USA) spectrophotometer. Optical spectra presented in this work were obtained by subtraction of the spectra of pure supports from the spectra of silver samples.

Prior to any characterization described below, the samples were pretreated in hydrogen at $300{ }^{\circ} \mathrm{C}$ for $1 \mathrm{~h}$. The textural properties of samples were determined from nitrogen adsorption-desorption isotherms $\left(-196^{\circ} \mathrm{C}\right)$ recorded with a TriStar 3000 apparatus (Micromeritics, Norgross, GA, USA). Prior to experiments, samples were degassed at $300{ }^{\circ} \mathrm{C}$ in a vacuum for $5 \mathrm{~h}$.

Silver contents were measured by energy dispersive spectroscopy (EDS) in the JEOL-5300 scanning electronic microscope with a Kevex Superdry detector (JEOL, Tokyo, Japan). High resolution transmission electron microscopy (HRTEM) studies were carried out using a JEM 2100F microscope operating with a $200-\mathrm{kV}$ accelerating voltage. The samples were ground into a fine powder and dispersed ultrasonically in hexane at room temperature. Then, a drop of the suspension was put on a lacey carbon-coated $\mathrm{Cu}$ grid. At least ten representative images were taken for each sample. A particle size distribution was obtained by counting $c a .100$ particles for each sample. Chemical analysis of surface carried out by spectroscopy of dispersion energy (EDS) with X-Max detector $\left(80 \mathrm{~mm}^{2}\right)$ (Oxford Instruments, Oxfordshire, UK).

Synchrotron radiation X-ray diffraction (SR-XRD) experiments were carried out as described in [60]. Diffraction patterns of powdered materials were taken in transmission at $\lambda=0.68886 \AA$, using an Imaging Plate 2D detector (exposure time: $30 \mathrm{~min}$ ). In some cases, full Rietveld analysis [61,62] was carried out using the Jana2006 program [60].

XAFS experiments were carried out as described in [60]. The XANES spectra were taken in transmission. Primary processing of XAFS spectra was done using the IFEFFIT software package $[63,64]$. Extended analysis (EXAFS) was carried out only for the EXAFS spectra taken in situ at room temperature. The Fourier transforms were analyzed for $k=2.0-11.6 \AA^{-1}$ with the weight coefficient $k^{3}$ using the phases and amplitudes of photoelectrons scattering calculated in terms of the FEFF8 software [65].

The samples were characterized by X-ray photoelectron spectroscopy (XPS) with a SPECS GmbH custom-made system using a PHOIBOS 150 WAL hemispherical analyzer and a non-monochromated X-ray source (SPECS Surface Nano Analysis GmbH, Berlin, Germany). All of the data were acquired using $\mathrm{Al} \mathrm{K} \alpha$ X-rays $(1486.6 \mathrm{eV}, 200 \mathrm{~W})$. A pass-energy of $50 \mathrm{eV}$, a step size of $0.1 \mathrm{eV} /$ step and 
a high-intensity lens mode were selected. The diameter of the analyzed area was $3 \mathrm{~mm}$. Charging shifts were referenced against the $\mathrm{Ti} 2 \mathrm{p} 3 / 2$ peak of $\mathrm{TiO}_{2}$ at $458.8 \mathrm{eV}$. The pressure in the analysis chamber was maintained lower than $1 \times 10^{-8}$ mbar. The accuracy of the binding energy (BE) values is $\pm 0.1 \mathrm{eV}$. Spectra are presented without smoothing or background subtraction, with intensity in counts per second (CPS). Peak areas were estimated by calculating the integral of each peak after subtracting a Shirley-type background and fitting the experimental peak to a combination of Lorentzian/Gaussian lines with a $30 / 70$ proportion and keeping the same width on all lines.

\section{Conclusions}

Differences in sensitivity to oxidative and reductive pretreatments was revealed for $\mathrm{Ag} / \mathrm{Fe} / \mathrm{TiO}$, $\mathrm{Ag} / \mathrm{Mg} / \mathrm{TiO}_{2}$ and $\mathrm{Ag} / \mathrm{Ce} / \mathrm{TiO}_{2}$ catalysts in $\mathrm{CO}$ oxidation. The observed phenomena could not be explained taking into account the Ag particle size distributions measured by HRTEM in the interval 1-13 nm. However, they can be explained by the existence of Ag species with size $<1 \mathrm{~nm}$, non-visible in HRTEM, and their interaction with the supports. The present work is one of the few to address the problem of the identification and characterization of such subnanometer species undetectable by HRTEM and highlights their role as active species and the need to take them into account to understand integrally the catalysis by supported nanometals.

Acknowledgments: This research was supported by Government Program "Science" of Tomsk Polytechnic University, Grant No. 4.1187.2014/K, CONACYT Project 260409 and PAPIIT-UNAM Project IT200114 (Mexico), CSIC project 201480E077 and MINECO Project CTQ2013-41507-R (Spain). We gratefully thank O. Martynyuk, G. Torres Otañez, Z. I. Bedolla Valdez, E. Flores, F. Ruiz Medina, A. Olivas Sarabia, I. Gradilla, J. Mendoza, E. M. Aparicio Ceja, J. Peralta, David A. Domínguez, M. Sainz, R. Valdez Castro, M. Martínez, B. Acosta Ruelas, F. Ramírez Hernández and M. López Cisneros for valuable technical assistance.

Author Contributions: M.H. Farías, Y. Zubavichus and A. Pestryakov conceived of and designed the experiments. Y. Kotolevich, E. Kolobova E. Khramov and J. E. Cabrera Ortega performed the experiments. Y. Kotolevich and R. Zanella contributed synthesis procedures. Y. Kotolevich, M. H. Farias, V. Cortés Corberán, A. Pestryakov and N. Bogdanchikova analyzed the data. Y. Kotolevich, J. D. Mota-Morales, V. Cortés Corberán, A. Pestryakov and N. Bogdanchikova wrote the paper.

Conflicts of Interest: The authors declare no conflict of interest.

\section{Abbreviations}

The following abbreviations are used in this manuscript:

$\begin{array}{ll}\text { ac-HAADF/STEM } & \begin{array}{l}\text { aberration-corrected high angle annular dark field scanning transmission } \\ \text { electron microscopy } \\ \text { binding energy }\end{array} \\ \text { BE } & \text { Counts per second. } \\ \text { CPS } & \text { density functional theory } \\ \text { DFT } & \text { diffuse reflectance spectroscopy in ultraviolet and visible diapason } \\ \text { DRS } & \text { energy dispersive spectroscopy } \\ \text { EDS } & \text { extended X-ray absorption fine structure } \\ \text { EXAFS } & \text { Fourier-transform infrared spectroscopy of adsorbed CO. } \\ \text { FTIR CO } & \text { high resolution transmission electron microscopy } \\ \text { HRTEM } & \text { strong metal-support interaction } \\ \text { SMSI } & \text { synchrotron radiation X-ray diffraction } \\ \text { SR-XRD } & \text { thermal conductivity detector } \\ \text { TCD } & \text { temperature-programmed reduction } \\ \text { TPR } & \text { ultraviolet-visible spectroscopy } \\ \text { UV-VIS } & \text { X-ray photoelectron spectroscopy, } \\ \text { XPS } & \text { X-ray absorption near edge structure } \\ \text { XANES } & \text { water-gas shift reaction } \\ \text { WGS } & \end{array}$




\section{References}

1. Zhu, H.; Ma, Z.; Clark, J.C.; Pan, Z.; Overbury, S.H.; Dai, S. Low-temperature CO oxidation on Au/fumed $\mathrm{SiO}_{2}$-based catalysts prepared from $\mathrm{Au}(\mathrm{en})_{2} \mathrm{Cl}_{3}$ precursor. Appl. Catal. A. 2007, 326, 89-99. [CrossRef]

2. Bondarchuk, I.S.; Mamontov, G.V. Role of PdAg Interface in $\mathrm{Pd}-\mathrm{Ag} / \mathrm{SiO}_{2}$ Bimetallic Catalysts in Low Temperature Oxidation of Carbon Monoxide. Kinet. Catal. 2015, 56, 382-388. [CrossRef]

3. Mamontov, G.V.; Knyazev, A.S.; Paukshtis, E.A.; Vodyankina, O.V. Adsorption and conversion of ethylene glycol on the surface of Ag containing catalyst modified with phosphate. Kinet. Catal. 2013, 54, 735-743. [CrossRef]

4. Martynova, D.O.; Kibis, L.S.; Stonkus, O.A.; Vodyankina, O.V.; Izaak, T.I.; Slavinskaya, E.M.; Boronin, A.I. Synthesis and Catalytic Activity of Porous Blocked $\mathrm{Ag} / \mathrm{SiO}_{2}$ Composites in Low Temperature Carbon Monoxide Oxidation. Kinet. Catal. 2013, 54, 519-523. [CrossRef]

5. Morgan, K.; Inceesungvorn, B.; Goguet, A.; Hardacre, C.; Meunier, F.C.; Shekhtman, S.O. TAP studies on 2\% $\mathrm{Ag} / \mathrm{c}-\mathrm{Al}_{2} \mathrm{O}_{3}$ catalyst for selective reduction of oxygen in a $\mathrm{H}_{2}$-rich ethylene feed. Catal. Sci. Technol. 2012, 2, 2128-2133. [CrossRef]

6. Guerba, H.; Djellouli, B.; Petit, C.; Pitchon, V. CO oxidation catalyzed by Ag/SBA-15 catalysts: Influence of the hydrothermal treatment. C. R. Chim. 2014, 17, 775-784. [CrossRef]

7. Inceesungvorn, B.; López-Castro, J.; Calvino, J.J.; Bernal, S.; Meunier, F.C.; Hardacre, C.; Griffin, K.; Delgado, J.J. Nano-structural investigation of $\mathrm{Ag} / \mathrm{Al}_{2} \mathrm{O}_{3}$ catalyst for selective removal of $\mathrm{O}_{2}$ with excess $\mathrm{H}_{2}$ in the presence of $\mathrm{C}_{2} \mathrm{H}_{4}$. Appl. Catal. A Gene. 2011, 391, 187-193. [CrossRef]

8. Lippits, M.J.; Gluhoi, A.C.; Nieuwenhuys, B.E. A comparative study of the effect of addition of CeOx and $\mathrm{Li}_{2} \mathrm{O}$ on c- $\mathrm{Al}_{2} \mathrm{O}_{3}$ supported copper, silver and gold catalysts in the preferential oxidation of CO. Top. Catal. 2007, 44, 159-165. [CrossRef]

9. Imaoka, T.; Kitazawa, H.; Chun, W.-J.; Yamamoto, K. Finding the Most Catalytically Active Platinum Clusters With Low Atomicity. Angew. Chem. Int. Ed. 2015, 54, 9810-9815. [CrossRef] [PubMed]

10. Berr, M.J.; Schweinberger, F.F.; Döblinger, M.; Sanwald, K.E.; Wolff, C.; Breimeier, J.; Crampton, A.S.; Ridge, C.J.; Tschurl, M.; Heiz, U. Size-selected Subnanometer Cluster Catalysts on Semiconductor Nanocrystal Films for Atomic Scale Insight into Photocatalysis. Nano Lett. 2012, 12, 5903-5906. [CrossRef] [PubMed]

11. Vilar-Vidal, N.; Rivas, J.; Lopez-Quintela, M.A. Size dependent catalytic activity of reusable subnanometer copper(0) clusters. ACS Catal. 2012, 2, 1693-1697. [CrossRef]

12. Pestryakov, A.N.; Lunin, V.V.; Kharlanov, A.N.; Bogdanchikova, N.E.; Tuzovskaya, I.V. Electronic state of gold in supported clusters. Eur. Phys. J. D 2003, 24, 307-309. [CrossRef]

13. Bogdanchikova, N.; Pestryakov, A.; Farias, M.H.; Diaz, J.A.; Avalos, M.; Navarrete, J. Formation of TEMand XRD-undetectable gold clusters accompanying big gold particles on $\mathrm{TiO}_{2}-\mathrm{SiO}_{2}$ supports. Solid State Sci. 2008, 10, 908-914. [CrossRef]

14. Flytzani-Stephanopoulos, M.; Gates, B.C. Atomically Dispersed Supported Metal Catalysts. Annu. Rev. Chem. Biomol. Eng. 2012, 3, 545-574.

15. Sun, S.; Zhang, G.; Gauquelin, N.; Chen, N.; Zhou, J.; Yang, S.; Chen, W.; Meng, X.; Geng, D.; Banis, M.N.; et al . Single-atom Catalysis Using Pt/Graphene Achieved through Atomic Layer Deposition. Sci. Rep. 2013, 3, 1-9. [CrossRef]

16. Allard, L.F.; Flytzani-Stephanopoulos, M.; Overbury, S.H. Behavior of $\mathrm{Au}$ Species in $\mathrm{Au} / \mathrm{Fe}_{2} \mathrm{O}_{3}$ Catalysts Characterized by Novel In Situ Heating Techniques and Aberration-Corrected STEM Imaging. Microsc. Microanal. 2010, 16, 375-385. [CrossRef] [PubMed]

17. Lessard, J.D.; Valsamakis, I.; Flytzani-Stephanopoulos, M. Novel Au/ $\mathrm{La}_{2} \mathrm{O}_{3}$ and $\mathrm{Au} / \mathrm{La}_{2} \mathrm{O}_{2} \mathrm{SO}_{4}$ catalysts for the water-gas shift reaction prepared via an anion adsorption method. Chem. Commun. 2012, 48, 4857-4859. [CrossRef] [PubMed]

18. Lee, Y.; He, G.; Akey, A.J.; Si, R.; Flytzani-Stephanopoulos, M.; Herman, I.P. Raman Analysis of Mode Softening in Nanoparticle $\mathrm{CeO}_{2-\delta}$ and $\mathrm{Au}-\mathrm{CeO}_{2-\delta}$ during $\mathrm{CO}$ Oxidation. J. Am. Chem. Soc. 2011, 133, 12952-12955. [CrossRef] [PubMed]

19. Flytzani-Stephanopoulos, M. Gold Atoms Stabilized on Various Supports Catalyze the Water Gas Shift Reaction. Acc. Chem. Res. 2014, 47, 783-792. [CrossRef] [PubMed] 
20. Yang, M.; Li, S.; Wang, Y.; Herron, J.A.; Xu, Y.; Allard, L.F.; Lee, S.; Huang, J.; Mavrikakis, M.; Flytzani-Stephanopoulos, M. Catalytically active $\mathrm{Au}-\mathrm{O}(\mathrm{OH})_{\mathrm{X}}$ species stabilized by alkali ions on zeolites and mesoporous oxides. Science 2014, 364, 1498-1501. [CrossRef] [PubMed]

21. Carabineiro, S.A.C.; Chen, X.; Martynyuk, O.; Bogdanchikova, N.; Avalos-Borja, M.; Pestryakov, A.; Tavares, P.B.; Orfao, J.J.M.; Pereira, M.F.R.; Figueiredo, J.L. Gold supported on metal oxides for volatile organic compounds total oxidation. Catal. Today 2015, 244, 103-114. [CrossRef]

22. Carabineiro, S.A.C.; Bogdanchikova, N.; Pestryakov, A.; Tavares, P.B.; Fernandes, L.; Figueiredo, J.L. Gold nanoparticles supported on magnesium oxide for CO oxidation. Nanoscale Res. Lett. 2011, 6. [CrossRef] [PubMed]

23. Carabineiro, S.A.C.; Bogdanchikova, N.; Avalos-Borja, M.; Pestryakov, A.; Tavares, P.B.; Figueiredo, J.L. Gold supported on metal oxides for carbon monoxide oxidation. Nano Res. 2011, 4, 180-193. [CrossRef]

24. Shekhar, M.; Wang, J.; Lee, W.-S.; Williams, W.D.; Min Kim, S.; Stach, E.A.; Miller, J.T.; Delgass, W.N.; Ribeiro, F.H. Size and Support Effects for the Water-Gas Shift Catalysis over Gold Nanoparticles Supported on Model $\mathrm{Al}_{2} \mathrm{O}_{3}$ and $\mathrm{TiO}_{2}$. J. Am. Chem. Soc. 2012, 134, 4700-4708. [CrossRef] [PubMed]

25. Rodriguez, J.A.; Senanayake, S.D.; Stacchiola, D.; Liu, P. Hrbek, The Activation of gold and the water-gas shift reaction: Insights from Studies with model catalysts. J. Acc. Chem. Res. 2014, 47, 773-782. [CrossRef] [PubMed]

26. Hussain, A.; Gracia, J.; Nieuwenhuys, B.E.; Niemantsverdriet, J.W. (Hans) Explicit roles of $\mathrm{Au}$ and $\mathrm{TiO}_{2}$ in a bifunctional $\mathrm{Au} / \mathrm{TiO}_{2}$ catalyst for the water-gas shift reaction: A DFT Study. ChemCatChem 2013, 5, 2479-2488. [CrossRef]

27. Boccuzzi, F.; Chiorino, A.; Manzoli, M.; Andreeva, D.; Tabakova, T. FTIR Study of the low-temperature water-gas shift reaction on $\mathrm{Au} / \mathrm{Fe}_{2} \mathrm{O}_{3}$ and $\mathrm{Au} / \mathrm{TiO}_{2}$ Catalysts. J. Catal. 1999, 188, 176-185. [CrossRef]

28. Qu, Z.; Huang, W.; Cheng, M.; Bao, X. Restructuring and Redispersion of Silver on $\mathrm{SiO}_{2}$ under Oxidizing/Reducing Atmospheres and Its Activity toward CO Oxidation. J. Phys. Chem. B 2005, 109, 15842-15848. [CrossRef] [PubMed]

29. Pestryakov, A.N.; Lunin, V.V. Physicochemical study of active sites of metal catalysts for alcohol partial oxidation. J. Mol. Catal. A Chem. 2000, 158, 325-329. [CrossRef]

30. Tabakova, T.; Boccuzzi, F.; Manzoli, M.; Chiorino, A.; Andreeva, D. Characterization of nanosized gold, silver and copper catalysts supported on ceria. Stud. Surf. Sci. Catal. 2005, 155, 493-500.

31. Boccuzzi, F.; Chiorino, A.; Manzoli, M.; Andreeva, D.; Tabakova, T.; Ilieva, L.; Iadakiev, V. Gold, silver and copper catalysts supported on $\mathrm{TiO}_{2}$ for pure hydrogen production. Catal. Today 2002, 75, 169-175. [CrossRef]

32. Keshavaraja, A.; She, X.; Flytzani-Stephanopoulos, M. Selective catalytic reduction of NO with methane over Ag-alumina catalysts. Appl. Catal. B Environ. 2000, 27, L1-L9. [CrossRef]

33. Kolobova, E.; Pestryakov, A.; Shemeryankina, A.; Kotolevich, Y.; Martynyuk, O.; Tiznado Vazquez, H.J.; Bogdanchikova, N. Formation of silver active states in Ag/ZSM-5 catalysts for CO oxidation. Fuel 2014, 138, 65-71. [CrossRef]

34. Bogdanchikova, N.; Tuzovskaya, T.; Pestryakov, A.; Susarrey-Arce, A. Comparative study of formation and stabilization of gold and silver clusters and nanoparticles in mordenites. J. Nanosci. Nanotechnol. 2011, 11, 5476-5482. [CrossRef] [PubMed]

35. Green, I.X.; Tang, W.; Neurock, M.; Yates Jr, J.T. Spectroscopic Observation of Dual Catalytic Sites During Oxidation of $\mathrm{CO}$ on a $\mathrm{Au} / \mathrm{TiO}_{2}$ Catalyst. Science 2011, 333, 736-739. [CrossRef] [PubMed]

36. Parka, J.B.; Graciani, J.; Evans, J.; Stacchiola, D.; Ma, S.; Liu, P.; Nambu, A.; Fernández Sanz, J.; Hrbeka, J.; Rodriguez, J.A. High catalytic activity of $\mathrm{Au} / \mathrm{CeOx} / \mathrm{TiO}_{2}(110)$ controlled by the nature of the mixed-metal oxide at the nanometer level. PNAS 2009, 106, 4975-4980. [CrossRef] [PubMed]

37. Ma, Z.; Yin, H.; Dai, S. Influence of Preparation Methods on the performance of metal phosphate-supported gold catalysts in CO Oxidation. Catal. Lett. 2010, 138, 40-45. [CrossRef]

38. Ma, Z.; Yin, H.; Overbury, S.H.; Dai, S. Metal Phosphates as a New Class of Supports for Gold Nanocatalysts. Catal. Lett. 2008, 126, 20-30. [CrossRef]

39. Pestryakov, A.N.; Bogdanchikova, N.; Simakov, A.; Tuzovskaya, I.; Jentoft, F.; Farias, M.; Díaz, A. Catalytically active gold clusters and nanoparticles for CO oxidation. Surf. Sci. 2007, 601, 3792-3795. [CrossRef]

40. Pestryakov, A.; Tuzovskaya, I.; Smolentseva, E.; Bogdanchikova, N.; Jentoft, F.C.; Knop-Gericke, A. Formation of gold nanoparticles in zeolites. Int. J. Modern Phys. B 2005, 19, 2321-2326. [CrossRef] 
41. Smolentseva, E.; Bogdanchikova, N.; Simakov, A.; Pestryakov, A.; Avalos, M.; Farias, M.H.; Tompos, A.; Gurin, V. Catalytic activity of gold nanoparticles incorporated into modified zeolites. J. Nanosci. Nanotechnol. 2007, 7, 1882-1886. [CrossRef] [PubMed]

42. Bogdanchikova, N.; Meunier, F.C.; Avalos-Borja, M.; Breen, J.P.; Pestryakov, A. On the nature of the silver phases of $\mathrm{Ag} / \mathrm{Al}_{2} \mathrm{O}_{3}$ catalysts for reactions involving nitric oxide. Appl. Catal. B 2002, 36, 287-297. [CrossRef]

43. Pestryakov, A.N.; Lunin, V.V.; Bogdanchikova, N.E.; Petranovskii, V.P.; Knop-Gericke, A. Supported foam-silver catalysts for alcohol partial oxidation. Catal. Commun. 2003, 4, 327-331. [CrossRef]

44. Pestryakov, A.N.; Bogdanchikova, N.E.; Knop-Gericke, A. Alcohol selective oxidation over modified foam-silver catalysts. Catal. Today. 2004, 91-92C, 49-52. [CrossRef]

45. Ershov, B.; Abkhalimov, E.; Sukhov, N. Formation of Long-Lived Clusters and Silver Nucleation in the g-Irradiation of Aqueous Silver Perchlorate Solutions Containing Polyphosphate. High Energ. Chem. 2005, 39, 83-87. [CrossRef]

46. Rtimi, S.; Baghrichea, O.; Sanjines, R.; Pulgarina, C.; Bensimonc, M.; Kiwi, J. TiON and TiON-Ag sputtered surfaces leading to bacterial inactivation under indoor actinic light. J. Photochem. Photobiol. A 2013, 256, 52-63.

47. Mejia, I.M.; Marín, M.; Sanjines, R.; Pulgarín, C.; Mielczarski, E.; Mielczarski, J.; Kiwi, L. Magnetron-sputtered Ag-modified cotton textiles active in the inactivation of airborne bacteria. ACS Appl. Mater. Interfaces 2010, 2, 230-235.

48. Wagner, C.D.; Riggs, M.; Davis, E.; Müllenberg, G. Handbook of X-ray Photoelectron Spectroscopy; Perkin-Elmer Corp. Physical Electronics Division: Eden Prairie, MN, USA, 1979; pp. 1-190.

49. Pestryakov, A.N.; Davydov, A.A. Active electronic states of silver catalysts for methanol selective oxidation. Appl. Catal. A 1994, 120, 7-15. [CrossRef]

50. Pestryakov, A. Modification of silver catalysts for oxidation of methanol to formaldehyde. Catal. Today 1996, 239-244. [CrossRef]

51. Yang, F.; Graciani, J.; Evans, J.; Liu, P.; Hrbek, J.; Sanz, J.F.; Rodriguez, J.A. CO Oxidation on inverse $\mathrm{CeOx} / \mathrm{Cu}(111)$ catalysts: High catalytic activity and ceria-promoted dissociation of $\mathrm{O}_{2}$. J. Am. Chem. Soc. 2011, 133, 3444-3451. [CrossRef] [PubMed]

52. Rao, K.N.; Bharali, P.; Thrimurthulu, G.; Reddy, B.M. Supported copper-ceria catalysts for low temperature CO oxidation. Catal. Commun. 2011, 11, 863-866. [CrossRef]

53. Kuzmicheva, G.M. Nanosized phases with titanium(iv) oxides. Preparation. Characterisation. Properties. Fine Chem. Technol. 2015, 10, 5-36.

54. Lopez-Salido, I.; Lim, D.C.; Kim, Y.D. Ag nanoparticles on highly ordered pyrolytic graphite (HOPG) surfaces studied using STM and XPS. Surf. Sci. 2005, 588, 6-18. [CrossRef]

55. Lim, D.C.; Lopez-Salido, I.; Kim, T.D. Size selectivity for CO-oxidation of Ag nanoparticles on highly ordered pyrolytic graphite (HOPG). Surf. Sci. 2005, 598, 96-103. [CrossRef]

56. Ahmad, M.Z.; Golovko, V.B.; Adnan, R.H.; Abu Bakar, F.; Ruzicka, J.; Anderson, D.P.; Andersson, G.G.; Wlodarski, W. Hydrogen sensing using gold nanoclusters supported on tungsten trioxide thin film. Int. J. Hydrog. Energy 2013, 38, 2865-2877. [CrossRef]

57. Zanella, R.; Giorgio, S.; Henry, C.R.; Louis, C. Alternative Methods for the Preparation of Gold Nanoparticles Supported on $\mathrm{TiO}_{2}$. Phys. Chem. B 2002, 106, 7634. [CrossRef]

58. Zanella, R.; Delannoy, L.; Louis, C. Mechanism of deposition of gold precursors onto $\mathrm{TiO}_{2}$ during the preparation by cation adsorption and deposition-precipitation with $\mathrm{NaOH}$ and urea. Appl. Catal. A 2005, 291, 62-72. [CrossRef]

59. Zanella, R.; Louis, C. Influence of the conditions of thermal treatments and of storage on the size of the gold particles in $\mathrm{Au} / \mathrm{TiO}_{2}$ samples. Catal. Today 2005, 107-108, 768-777. [CrossRef]

60. Chernyshov, A.A.; Veligzhanin, A.A.; Zubavichus, Y.V. Structural materials science end-station at the Kurchatov synchrotron radiation source: Recent instrumentation upgrades and experimental results. Nucl. Instrum. Methods Phys. Res. A 2009, 603, 95-98. [CrossRef]

61. Petricek, V.; Dusek, M.; Palatinus, L. Jana2006: The CRYSTALLOGRAPHIC computing System. Institute of Physics: Praha, Czech Republic, 2006. Available online: http://jana.fzu.cz/ (accessed on 25 January 2016).

62. Rietveld, H.M. A profile refinement method for nuclear and magnetic structures. J. Appl. Crystallogr. 1969, 2, 65-71. [CrossRef] 
63. Athena, R.B.; Hephaestus, A. Data analysis for X-ray absorption spectroscopy using IFEFFIT. J. Synchrotron Rad. 2005, 12, 537-541.

64. Newville, M. IFEFFIT: Interactive XAFS analysis and IFEF fitting. J. Synchrotron Rad. 2001, 8, 322-324. [CrossRef]

65. Ankudinov, A.L.; Ravel, B.; Rehr, J.J.; Conradson, S.D. Real-space multiple-scattering calculation and interpretation of X-ray-absorption near-edge structure. Phys. Rev. B 1998, 58, 7565-7576. [CrossRef]

Sample Availability: All studied samples are available from the authors.

(C) 2016 by the authors; licensee MDPI, Basel, Switzerland. This article is an open access article distributed under the terms and conditions of the Creative Commons Attribution (CC-BY) license (http://creativecommons.org/licenses/by/4.0/). 